\title{
Crustal influx, indentation, ductile thinning and gravity redistribution in a continental wedge: Building a Moldanubian mantled gneiss dome with underthrust Saxothuringian material (European Variscan belt)
}

\author{
F. Chopin, ${ }^{1,2}$ K. Schulmann, ${ }^{1}$ E. Skrzypek, ${ }^{1}$ J. Lehmann,,${ }^{1,3}$ J. R. Dujardin, ${ }^{1}$ J. E. Martelat, ${ }^{4}$ \\ O. Lexa, ${ }^{3,5}$ M. Corsini, ${ }^{2}$ J. B. Edel, ${ }^{1}$ P. Štípská, ${ }^{1}$ and P. Pitra ${ }^{6}$ \\ Received 22 May 2011; revised 15 December 2011; accepted 21 December 2011; published 28 February 2012.
}

[1] The contribution of lateral forces, vertical load, gravity redistribution and erosion to the origin of mantled gneiss domes in internal zones of orogens remains debated. In the Orlica-Śnieżnik dome (Moldanubian zone, European Variscan belt), the polyphase tectono-metamorphic history is initially characterized by the development of subhorizontal fabrics associated with medium- to high-grade metamorphic conditions in different levels of the crust. It reflects the eastward influx of a Saxothuringian-type passive margin sequence below a Teplá-Barrandian upper plate. The ongoing influx of continental crust creates a thick felsic orogenic root with HP rocks and migmatitic orthogneiss. The orogenic wedge is subsequently indented by the eastern Brunia microcontinent producing a multiscale folding of the orogenic infrastructure. The resulting kilometre-scale folding is associated with the variable burial of the middle crust in synforms and the exhumation of the lower crust in antiforms. These localized vertical exchanges of material and heat are coeval with a larger crustal-scale folding of the whole infrastructure generating a general uplift of the dome. It is exemplified by increasing metamorphic conditions and younging of ${ }^{40} \mathrm{Ar}{ }^{39} \mathrm{Ar}$ cooling ages toward the extruded migmatitic subdomes cored by HP rocks. The vertical growth of the dome induces exhumation by pure shear-dominated ductile thinning laterally evolving to non-coaxial detachment faulting, while erosion feeds the surrounding sedimentary basins. Modeling of the Bouguer anomaly grid is compatible with crustal-scale mass transfers between a dense superstructure and a lighter infrastructure. The model implies that the Moldanubian Orlica-Śnieżnik mantled gneiss dome derives from polyphase recycling of Saxothuringian material.

Citation: Chopin, F., et al. (2012), Crustal influx, indentation, ductile thinning and gravity redistribution in a continental wedge: Building a Moldanubian mantled gneiss dome with underthrust Saxothuringian material (European Variscan belt), Tectonics, 31, TC1013, doi:10.1029/2011TC002951.

\section{Introduction}

[2] Collisional orogens are sites of thickening and burial of the crust down to $70 \mathrm{~km}$ associated with the development of a topography reaching 5-6 km [Le Pichon et al., 1997;

\footnotetext{
${ }^{1}$ École et Observatoire des Sciences de la Terre, Institut de Physique du Globe, CNRS UMR 7516, Université de Strasbourg, Strasbourg, France.

${ }^{2}$ Géoazur, CNRS UMR 6526, Université de Nice, Sophia Antipolis, Nice, France.

${ }^{3}$ Czech Geological Survey, Prague, Czech Republic.

${ }^{4}$ Laboratoire de Géologie de Lyon, CNRS UMR 5276, Université Claude Bernard et École Normale Supérieure, Villeurbanne, France.

${ }^{5}$ Institute of Petrology and Structural Geology, Charles University, Prague, Czech Republic.

${ }^{6}$ Géosciences Rennes, CNRS UMR 6118, Université Rennes 1, Campus de Beaulieu, Rennes, France.

Copyright 2012 by the American Geophysical Union. 0278-7407/12/2011TC002951
}

Gapais et al., 2009]. Elongated or linear fold and thrust belts highlight the importance of horizontal movements and lateral shortening in the genesis of orogenic systems [e.g., Dewey and Bird, 1970]. However, a characteristic feature of some ancient collisional orogens is the development of circular or elliptical domal structures cored by high-grade rocks and surrounded by sedimentary basins - so-called mantled gneiss domes [Teyssier and Whitney, 2002] suggesting vertical movements in the crust [e.g., Brun, 1983]. These vertical movements may be intimately associated with horizontal displacements in specific types of large hot orogens where a subsurface horizontal channel flow produces asymmetrical dome-like structures [Whitney et al., 2004]. In addition, the growth of gneiss domes assisted by deep crustal channel flow and focused erosion was proposed by Beaumont et al. [2006]. Finally, the relative contributions of lateral compression, gravity redistribution and concomitant erosion can be studied in order to distinguish between 


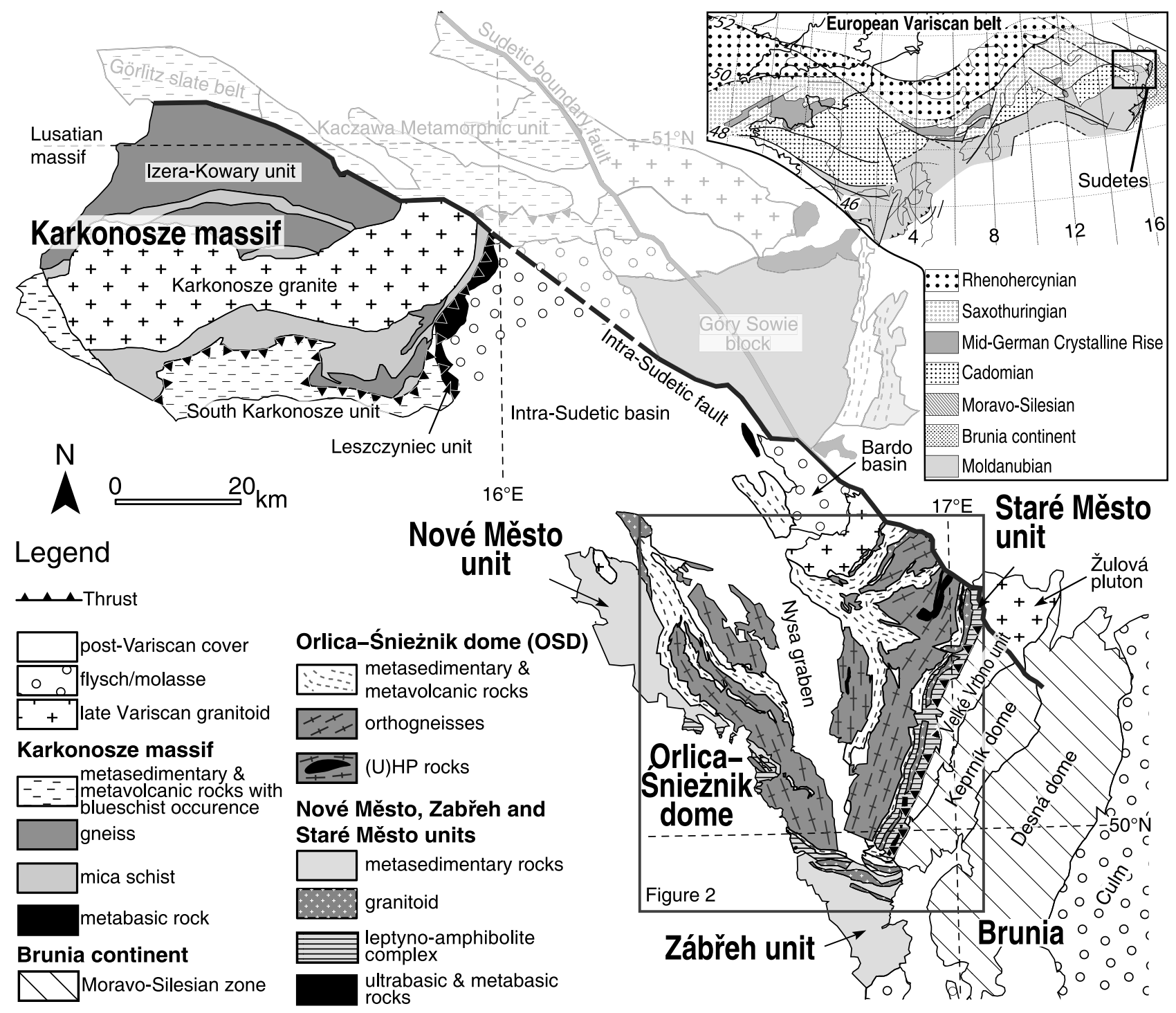

Figure 1. Simplified geological map of the Sudetes (modified after Aleksandrowski et al. [1997]). Upper left inset depicts the location of the study area within the European Variscan belt (modified after Edel et al. [2003]).

domes originating from folding or diapiric processes [Burg et al., 2004].

[3] The European Variscan belt shows the geometry of a continental accretionary wedge [Schulmann et al., 2009]. In the Bohemian Massif, the structure of the deep part of the orogen has been explained by the allochtonous feeding of a wedge-shaped root by felsic rocks of the subducting continental plate [Guy et al., 2010]. The subsequent exhumation of deeply buried crust is thought to be the result of gravitational overturns [Lexa et al., 2011] and/or crustal-scale folding [Štipská et al., 2004; Franěk et al., 2011; Skrzypek et al., 2011a]. The final increments of exhumation are controlled by lateral subsurface flow of the extruded lower crust underneath a rigid lid [Schulmann et al., 2005, 2008], similar to the ductile thinning process modeled by Koyi et al. [1999].

[4] In this work we study a crustal-scale mantled gneiss dome, the Orlica-Śnieżnik dome (OSD) in the Central
Sudetes (Figure 1). The OSD is cored by metasedimentary rocks, partly migmatitic orthogneiss, high-pressure (HP) granulite and eclogite, and is surrounded by low- to mediumgrade metasedimentary rocks. The overall structure of the dome can be, to a first approximation, interpreted as a classical mantled gneiss dome similar to crustal-scale structures reported from other orogenic belts [Eskola, 1948]. Further, we use a large database of structural, petrological and geochronological data together with $2 \mathrm{D}$ gravity modeling to propose a model of influx of continental crust in the orogenic wedge leading to the development of an orogenic infra- and superstructure [Haller, 1956], and explaining the formation of the OSD. An attempt is made to distinguish between the simultaneous exhumation and burial of rocks operating in kilometre-scale antiforms and synforms, and the larger-scale growth of the dome several tens of kilometres in diameter. Finally, we discuss the relative influence of ductile thinning, erosion and large-scale detachment of the superstructure on 


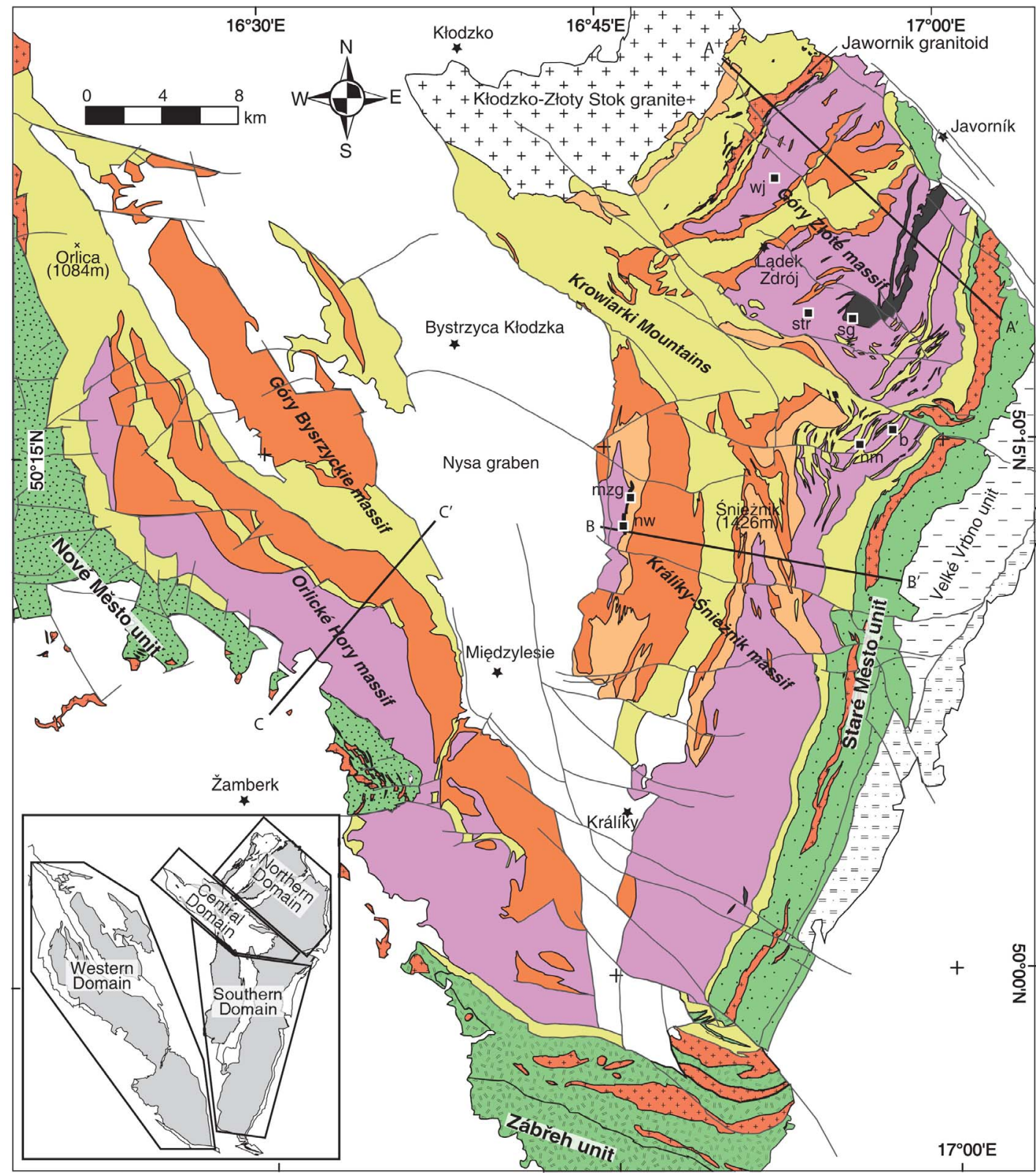

\section{Orlica-Śnieżnik dome (OSD)}

OSD mantle

\section{$\because \because$ Nové Město unit: metasedimentary \& metavolcanic rocks \\ Zábřeh unit: metasedimentary \& metavolcanic rocks \\ Staré Město unit: metabasic rock, migmatites}

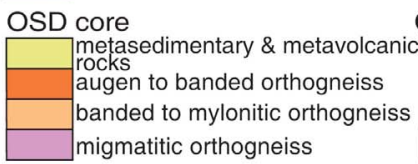

OSD (U)HP

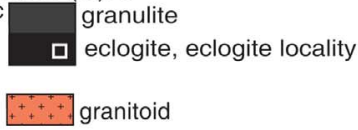

\section{Brunia}

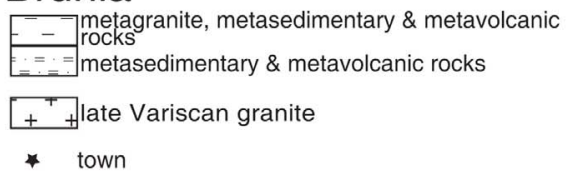

Abbreviations for eclogite localities are: $\mathrm{mzg}=$ Międzygórze nw=Nowa Wieś, wj=Wójtówka, str=Strachocin, sg=Stary Gieraltów, $\mathrm{b}=$ Bielice, $\mathrm{nm}=$ Nowa Morawa.

Figure 2. Lithological map of the Orlica-Śnieżnik dome (OSD) (modified after Don et al. [2003], Żelaźniewicz et al. [2006], and geological maps from the Czech Geological Survey 1:25,000, 1:50,000 and the Polish Geological Institute 1:100,000). Locations of cross sections are indicated. Inset shows the position of the different structural domains. 


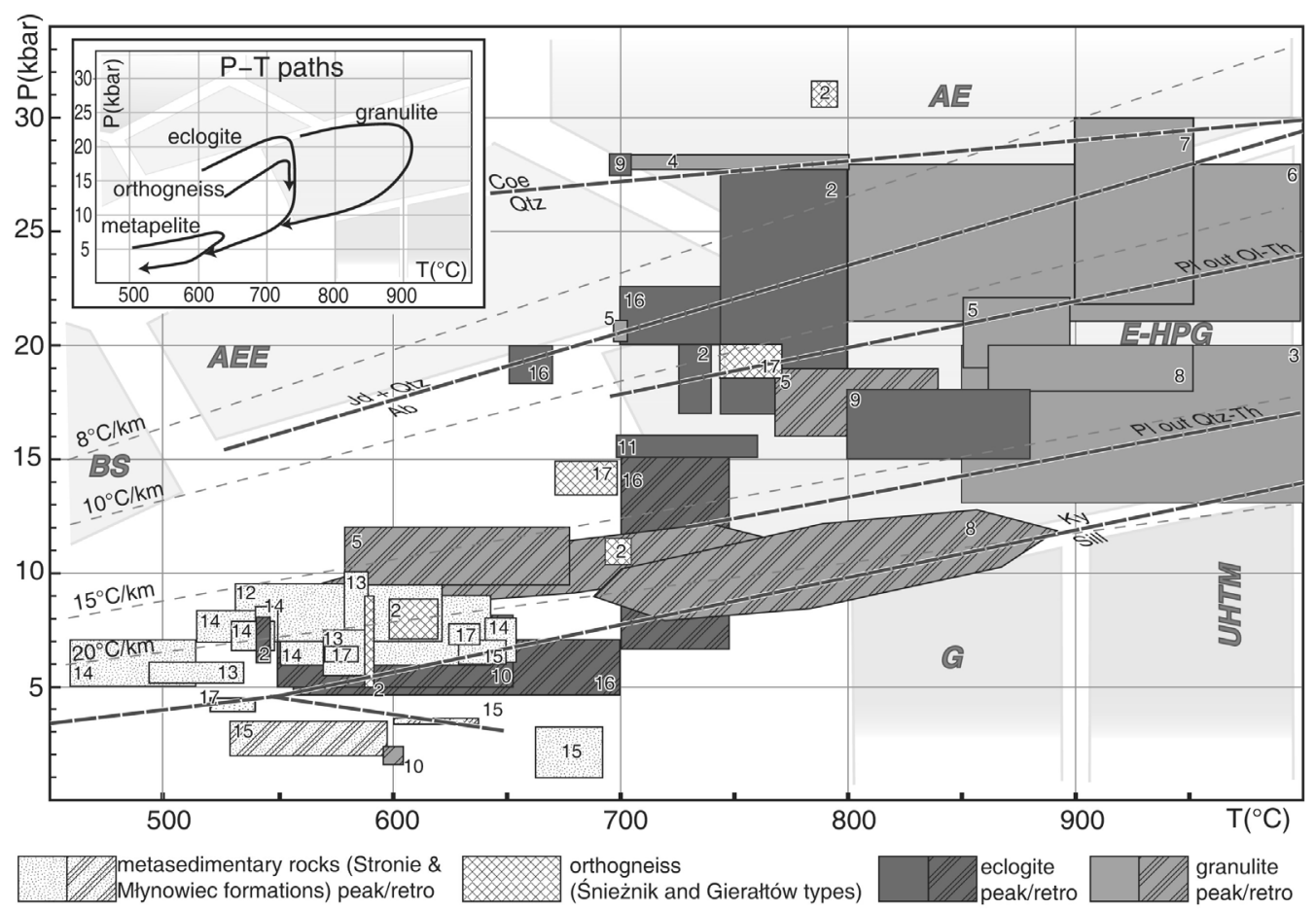

Figure 3. Compilation of earlier reported $\mathrm{P}-\mathrm{T}$ data for metapelite, orthogneiss, and (U)HP rocks in the OSD. Mean P-T paths are shown in the inset. High-grade metamorphic facies are after Brown [2007]. BS: blueschist facies; AEE: amphibole-epidote eclogite facies; ALE: amphibole-lawsonite eclogite facies; LE: lawsonite eclogite facies; AE: amphibole eclogite facies; GS: greenschist facies; A: amphibolite facies; E-HPG: medium-temperature eclogite facies-high-pressure granulite metamorphism; G: granulite facies; UHTM: ultra-high-temperature metamorphic part of the granulite facies. References of P-T data: see Table 1.

the exhumation of the infrastructure in the core of the dome. This approach allows detailed discussion of the interplay between gravity and lateral shortening during the formation of one of the largest gneiss domes in Variscan Europe.

\section{Tectonic Setting}

[5] The Sudetes form the easternmost part of the European Variscides and show a complex mosaic of terranes [Franke and Żelaźniewicz, 2000; Aleksandrowski and Mazur, 2002]. From the NW to SE, lithological units with different tectonic affinities build up a nearly continuous section of a convergent orogenic system (Figure 1). In the NW Karkonosze Massif, undeformed Neoproterozoic basement rocks (Lusatian massif) are intruded by Late Cambrian-Early Ordovician granitoids later transformed into orthogneiss during Devonian-Carboniferous collision. The latter are tectonically intercalated with slivers of metasedimentary rocks to form the para-autochtonous Izera-Kowary unit [Mazur and Aleksandrowski, 2001]. This structurally lowermost unit of the Karkonosze massif is overlain toward the SE by relicts of an accretionary prism (South Karkonosze unit) and obducted remnants of Ordovician oceanic crust (Leszczyniec unit) [Mazur and Kryza, 1996; Mazur and Aleksandrowski, 2001; Mazur et al., 2006]. These allochtonous units are weakly to highly deformed at greenschist- to blueschist-facies conditions as a result of Late Devonian to Carboniferous subduction and accretion [Maluski and Patočka, 1997]. The whole
Karkonosze massif can therefore be considered as a metamorphosed passive margin sequence of the Saxothuringian basin abutting against the Teplá/Saxothuringian suture zone [Mazur and Aleksandrowski, 2001; Žáčková et al., 2010].

[6] Farther to the SE, the Nové Město and Zábřeh units as well as part of the unknown basement of the syn- to postorogenic IntraSudetic basin are correlated with the TepláBarrandian Neoproterozoic crust [Mazur and Aleksandrowski, 2001; Mazur et al., 2005] (Figure 1). These low- to mediumgrade units surround the medium- to high-grade rocks of the Orlica-Śnieżnik dome which is considered as the root of the orogen [Svoboda, 1966; Fajst, 1976; Štipská et al., 2004] and is commonly correlated with the Moldanubian zone observed elsewhere in the Bohemian Massif [e.g., Matte et al., 1990]. To the east, the OSD is juxtaposed with remnants of a Late Cambrian-Early Ordovician intracontinental rift system found in the Staré Město unit [Kröner et al., 2000; Štipská et al., 2001]. Farther east, the Moravo-Silesian zone consists of a fragmented Neoproterozoic basement derived from the Brunia microcontinent (Velké Vrbno unit, Keprník and Desná domes) [Schulmann and Gayer, 2000] which is covered by Devonian sediments and Early Carboniferous Culm facies clastics.

\section{Geology of the Orlica-Śnieżnik Dome}

[7] The Orlica-Śnieżnik dome forms a mantled gneiss dome which is rimmed by the low- to medium-grade rocks 
Table 1. Summary of Published P-T Data in the Orlica-Śnieżnik Dome ${ }^{\mathrm{a}}$

\begin{tabular}{|c|c|c|c|c|}
\hline Rock Type and Locality & $\mathrm{P}$ (kbar) & $\mathrm{T}\left({ }^{\circ} \mathrm{C}\right)$ & Interpretation & Reference $^{b}$ \\
\hline \multicolumn{5}{|c|}{ Orthogneiss } \\
\hline SD and C.D. & $5.5-6.5$ & $550-650$ & Retrograde & (1) Kozłowska-Koch [1973] \\
\hline SD and C.D. & 31 & 790 & UHP-Peak & (2) Bröcker and Klemd [1996] \\
\hline SD and C.D. & 11 & 700 & UHP-Peak & (2) Bröcker and Klemd [1996] \\
\hline SD and C.D. & $7-9$ & $600-620$ & Retrograde & (2) Bröcker and Klemd [1996] \\
\hline SD and C.D. & $4-9$ & 600 & Retrograde & (2) Bröcker and Klemd [1996] \\
\hline SD (Międzygórze) & $<15$ & $<700$ & Prograde & (17) Chopin et al. [2012] \\
\hline SD (Międzygórze) & $18-20$ & $>750$ & HP-Peak & (17) Chopin et al. [2012] \\
\hline \multicolumn{5}{|c|}{ HP Granulite } \\
\hline N.D. & $13-20$ & $850-1000$ & HP-Peak & (3) Pouba et al. [1985] \\
\hline N.D. & 28 & $700-800$ & UHP-Peak & (4) Bakun-Czubarow [1992] \\
\hline N.D. & $20-21$ & 700 & Prograde & (5) Steltenpohl et al. [1993] \\
\hline N.D. & $19-22$ & $850-900$ & HP-Peak & (5) Steltenpohl et al. [1993] \\
\hline N.D. & $16-19$ & $770-840$ & Retrograde & (5) Steltenpohl et al. [1993] \\
\hline N.D. & $9.5-12.5$ & $580-680$ & Retrograde & (5) Steltenpohl et al. [1993] \\
\hline SD (Stary Gierałtów) & $21-28$ & $800-1000$ & UHP-Peak & (6) Klemd and Bröcker [1999] \\
\hline N.D. & $>22$ & $>900$ & Peak & (7) Kryza et al. [1996] \\
\hline N.D. (Červený Důl) & 18 & 900 & Peak & (8) Štipská et al. [2004] \\
\hline N.D. (Červený Důl) & 10 & 700 & Retrograde & (8) Stipská et al. [2004] \\
\hline \multicolumn{5}{|c|}{ Eclogite } \\
\hline SD (Nowa Wieś) & - & $560-620$ & Peak & (18) Smulikowski and Smulikowski [1985] \\
\hline SD (Wójtówka) & - & $560-620$ & Peak & (18) Smulikowski and Smulikowski [1985] \\
\hline N.D.? & 28 & $700 ?$ & UHP-Peak & (9) Bakun-Czubarow [1991] \\
\hline N.D.? & $15-18$ & $800-880$ & Peak & (9) Bakun-Czubarow [1991] \\
\hline SD and C.D. & $5-8$ & $550-650$ & Retrograde & (10) Klemd et al. [1995] \\
\hline SD and C.D. & 2 & 600 & Retrograde & (10) Klemd et al. [1995] \\
\hline SD and C.D. & 2 & 200 & Retrograde & (10) Klemd et al. [1995] \\
\hline SD and C.D. & $17-28$ & $745-795$ & UHP-Peak & (2) Bröcker and Klemd [1996] \\
\hline SD and C.D. & $17-20$ & $725-740$ & UHP-Peak & (2) Bröcker and Klemd [1996] \\
\hline SD and C.D. & $6-8$ & 545 & Retrograde & (2) Bröcker and Klemd [1996] \\
\hline SD (Stary Gierałtów) & $15-16$ & $700-760$ & UHP-Peak & (11) Bakun-Czubarow [1998] \\
\hline SD (Międzygórze) & 22 & 720 & HP-Peak & (16) Štipská et al. [2012] \\
\hline SD (Międzygórze) & 10 & 700 & Retrograde & (16) Štípská et al. [2012] \\
\hline SD (Międzygórze) & 5 & 600 & Retrograde & (16) Štípská et al. [2012] \\
\hline \multicolumn{5}{|c|}{ Metasediment (Stronie and Mtynowiec Formation) } \\
\hline W.D. (Zdobnice N) & $2.2-6.5$ & $250-400$ & Prograde & (12) Mazur et al. [2005] \\
\hline W.D. (Zdobnice $\mathrm{N}$ and $\mathrm{S}$ ) & $6.9-9.6$ & $535-623$ & Peak & (12) Mazur et al. [2005] \\
\hline N.D. (Orłowiec) & $7-10$ & $580-590$ & Peak & (13) Murtezi [2006] \\
\hline C.D. (Kąty Bystrzyckie) & $5.5-7.5$ & $570-590$ & Peak & (13) Murtezi [2006] \\
\hline W.D. (Gniewoszów) & $5.2-6.1$ & $495-540$ & Peak & (13) Murtezi [2006] \\
\hline N.D. (Lądek Zdrój) & $9-10$ & 510 & Peak P & (14) Jastrzębski [2009] \\
\hline N.D. (Lądek Zdrój) & $7-8$ & 620 & Peak T & (14) Jastrzębski [2009] \\
\hline N.D. (Lądek Zdrój) & $6-8$ & $640-655$ & Peak T & (14) Jastrzębski [2009] \\
\hline C.D. (Stronie Śląskie) & $5.7-9$ & $555-640$ & Peak T & (14) Jastrzębski [2009] \\
\hline C.D. (Romanowo) & $7-8.3$ & $515-545$ & Peak T & (14) Jastrzębski [2009] \\
\hline E.D. (Gniewoszów) & $5-7$ & $460-515$ & Peak T & (14) Jastrzębski [2009] \\
\hline N.D. (Javorník-Travná) & $3.5-5$ & $490-520$ & Prograde & (15) Skrzypek et al. [2011a] \\
\hline N.D. (Javorník-Travná) & $6-7$ & $630-650$ & Peak $\mathrm{P}$ and $\mathrm{T}$ & (15) Skrzypek et al. [2011a] \\
\hline N.D. (Javorník-Travná) & 4 & 630 & Retrograde & (15) Skrzypek et al. [2011a] \\
\hline N.D. (Javorník-Travná) & $4-4.5$ & $490-510$ & Prograde & (15) Skrzypek et al. [2011b] \\
\hline N.D. (Javorník-Travná) & $5-6$ & $520-550$ & Prograde & (15) Skrzypek et al. [2011b] \\
\hline N.D. (Javorník-Travná) & $6.5-7.5$ & $560-590$ & Peak $\mathrm{P}$ and $\mathrm{T}$ & (15) Skrzypek et al. [2011b] \\
\hline N.D. (Javorník-Travná) & $2-3.5$ & $530-600$ & Retrograde & (15) Skrzypek et al. [2011b] \\
\hline SD (Mariańskie Skały) & $5-7$ & $520-610$ & Prograde & (16) Stipská et al. [2012] \\
\hline SD (Mariańskie Skały) & 7.5 & 630 & Peak $\mathrm{P}$ and $\mathrm{T}$ & (16) Štípská et al. [2012] \\
\hline SD (Mariańskie Skały) & $4-4.5$ & $520-540$ & Retrograde & (16) Štípská et al. [2012] \\
\hline
\end{tabular}

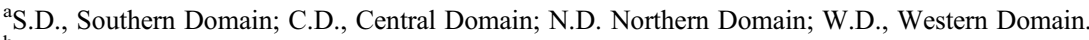

${ }^{\mathrm{b}}$ Numbers in parentheses refer to data in Figure 3.

of the Nové Město unit to the west, the Zábřeh unit to the south, and the Staré Město unit to the east (Figure 1) [Fajst, 1976]. Its general structure has previously been explained by eastward stacking of crystalline nappes and oblique thrusting of the Central Sudetes over the subducted MoravoSilesian zone in a continental accretionary wedge configuration [Borkowska et al., 1990; Don et al., 1990; Cymerman,
1997; Schulmann and Gayer, 2000; Żelaźniewicz et al., 2002; Pressler et al., 2007].

\subsection{Lithology and Metamorphism of the OSD Core}

[8] Metagranitic orthogneiss represents the main lithology of the OSD (Figure 2) and is classically subdivided into two types: the augen to banded Śnieżnik type, and the 
fine-grained mylonitic to migmatic Gieraltów type [Fischer, 1936; Don et al., 1990]. Recent studies have proposed that both orthogneiss types result from the deformation and metamorphism of the same protolith and chiefly reflect variations in strain intensity [Turniak et al., 2000; Lange et al., 2005b; Chopin et al., 2012]. The second important lithology corresponds to the Młynowiec (paragneiss \pm mica schist and amphibolite) and Stronie (mica schist \pm paragneiss, quartzite, graphite schist, marble, acid and basic metavolcanics) metasedimentary formations [Fischer, 1936; Vangerow, 1943; Don et al., 1990, 2003] (Figure 2). Eclogites mostly occur along a narrow $\mathrm{N}-\mathrm{S}$ trending belt within orthogneiss in the center of the dome (Králíky-Śnieżnik massif) or appear as isolated boudins in the eastern part of the OSD [Smulikowski, 1967]. HP granulites are restricted to a narrow and elongated belt in the northeastern part of the dome [Kozłowski, 1961; Pouba et al., 1985] (Figure 2).

[9] The metapelites show increasing metamorphic grade from west to east [Jastrzębski, 2009], and preserve variable peak metamorphic conditions between 5-9 kbar and 460650 ${ }^{\circ} \mathrm{C}$ [Murtezi, 2006; Jastrzębski, 2009; Skrzypek et al., 2011a] (Figure 3 and Table 1). Although UHP metamorphism possibly reaching $30 \mathrm{kbar}$ has been suggested for high-grade lithologies [e.g., Bröcker and Klemd, 1996], peak $\mathrm{P}-\mathrm{T}$ conditions of $19-22 \mathrm{kbar}$ at $\sim 700-750^{\circ} \mathrm{C}$ that have been estimated by Śtípská et al. [2012] for eclogites are compatible with metamorphic conditions of 19-20 kbar at temperatures higher than $700^{\circ} \mathrm{C}$ in the adjacent orthogneisses [Chopin et al., 2012] (Figure 3 and Table 1). In (U) HP granulites, metamorphism reached peak pressures similar to those proposed for eclogites, but higher peak temperature conditions of $800-1000^{\circ} \mathrm{C}$ [Kryza et al., 1996; Stipská et al., 2004]. Retrograde metamorphism has been estimated at 5-8 kbar and $550-700^{\circ} \mathrm{C}$ for eclogites [Śtípská et al., 2012], and at $8-12 \mathrm{kbar}$ and $580-720^{\circ} \mathrm{C}$ for HP granulites [Štípská et al., 2004] (Figure 3 and Table 1).

\subsection{Geochronology of the OSD Core}

[10] The sedimentary precursors of the Młynowiec and Stronie formations were probably deposited during the Neoproterozoic and the Lower Cambrian, respectively [Mazur et al., 2012]. In the orthogneiss, the U-Pb protolith ages of 510-490 Ma [e.g., Mazur et al., 2010] indicate that this sedimentation was followed by a widespread episode of Late Cambrian granitic magmatism (Figure 4a; see Table S1 in the auxiliary material for age references). ${ }^{1}$ Inherited zircon ages additionally suggest that sedimentation in the Stronie formation was followed in the Early Ordovician by the deposition of the Goszów quartzite [Mazur et al., 2012]. In contrast, protolith ages for HP rocks are younger and cluster at 470$460 \mathrm{Ma}$.

[11] The U-Pb, Lu-Hf, Rb-Sr or Sm-Nd dating techniques [see Bröcker et al., 2009, and references therein] point to a major metamorphic event at c. $340 \mathrm{Ma}$ (Figures $4 \mathrm{a}$ and $4 \mathrm{~b}$ and Table S1). It has been clearly recognized in the orthogneiss (Figures $4 \mathrm{a}$ and $4 \mathrm{~b}$ ) and eclogite (Figures $4 \mathrm{a}$ and $4 \mathrm{c}$ ), whereas metamorphic ages in the HP granulite belt

\footnotetext{
${ }^{1}$ Auxiliary materials are available in the HTML. doi:10.1029/ $2011 \mathrm{TC} 002951$.
}

and adjacent migmatitic rocks are more dispersed between 390 and $320 \mathrm{Ma}$ with a pronounced peak at $340 \mathrm{Ma}$ (Figures $4 \mathrm{a}$ and $4 \mathrm{c}$ ). Granodiorite intrusions rimming the OSD core yield uniform ages of c. 340 Ma [Štípská et al., 2004], but the NE granite sill located within the OSD core (Jawornik granite) shows an older crystallization age of c. $350 \mathrm{Ma}$ (Figure 4a) (see unpublished data by A. Kröner in the work of Biatek and Werner [2004]).

\subsection{Lithology and Metamorphism of the OSD Mantle Units}

[12] The Staré Město unit (Figure 2) is located at the boundary zone between the OSD and the Brunia microcontinent [Parry et al., 1997; Kröner et al., 2000; Schulmann and Gayer, 2000]. It forms a NNE-SSW trending belt composed of Early Ordovician amphibolite, tonalitic gneiss, paragneiss and migmatite. To the south and west, the metasedimentary rocks and massive amphibolite of the Zábřeh and Nové Město units that have most probably Neoproterozoic protoliths [Mazur and Aleksandrowski, 2001] are intruded by numerous granitoid sills [Parry et al., 1997; Lehmann, 2009; Verner et al., 2009] and are overlain by Early Carboniferous clastic sediments [Opletal et al., 1980; Mazur et al., 2005].

[13] Rocks from the Staré Město unit are thought to document two distinct Cambro-Ordovician and Variscan metamorphic events with conditions of 7.5-10 kbar and $730-860^{\circ} \mathrm{C}$, and $6.5-10 \mathrm{kbar}$ and $670-760^{\circ} \mathrm{C}$, respectively [Štípská et al., 2001; Lexa et al., 2005]. The Nové Město and the Zábřeh units preserve a low- to medium-grade metamorphic overprint manifested by a narrow Barrovian gradient increasing toward the boundary with the OSD core [Mazur et al., 2005; Buriánek et al., 2009].

\section{4. ${ }^{40} \mathrm{Ar} /{ }^{39} \mathrm{Ar}$ Geochronology}

[14] There is an extensive database of ${ }^{40} \mathrm{Ar} /{ }^{39} \mathrm{Ar}$ ages [e.g., Bröcker et al., 2009] showing that most of the cooling ages cluster between 350 and $330 \mathrm{Ma}$ (Figure 4c and Table S1). This data set was compiled and complemented in order to better constrain the spatial distribution of possible age domains. The location of new and earlier reported ${ }^{40} \mathrm{Ar} /{ }^{39} \mathrm{Ar}$ data is presented in Figure 4, new ${ }^{40} \mathrm{Ar} /{ }^{39} \mathrm{Ar}$ step-release spectra are shown in Figure 5, and raw data can be found as auxiliary material (Tables S2-S9).

\section{1. ${ }^{40} \mathrm{Ar} /{ }^{39} \mathrm{Ar}$ Geochronology of the OSD Core}

[15] Apart from ${ }^{40} \mathrm{Ar} /{ }^{39} \mathrm{Ar}$ ages of Bialek and Werner [2004], no age data are available for the NE part of the OSD core. Consequently, two metapelite samples from the Stronie formation were collected at $300 \mathrm{~m}$ (JL14A), and at few meters (JL11A) NW from the contact with the Jawornik intrusion located in the northern part of the OSD (Figures 2 and $4 \mathrm{~d}$ ). Both samples contain quartz, biotite, muscovite and opaque minerals with additional garnet in sample JL11A. They show a subvertical metamorphic foliation which is defined by the alternation of quartz-rich and mica-rich layers. These two samples yielded muscovite plateau ages of $347.9 \pm 8.6 \mathrm{Ma}(\mathrm{JL} 14 \mathrm{~A})$ and $335.2 \pm 12.6 \mathrm{Ma}$ (JL11A) (Figure 5) which overlap within error with the muscovite and hornblende cooling ages of 351-343 Ma from the 

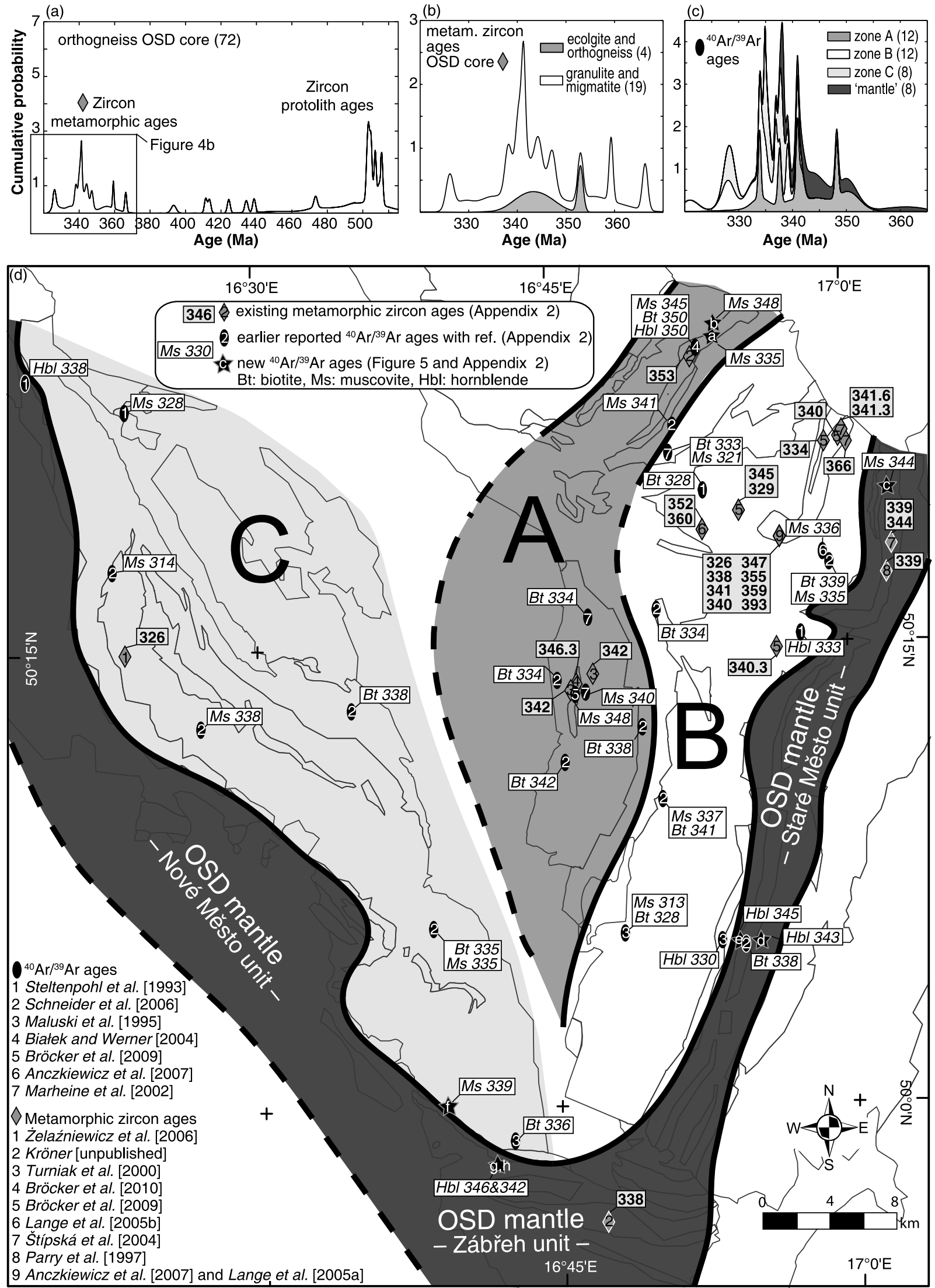

Figure 4 

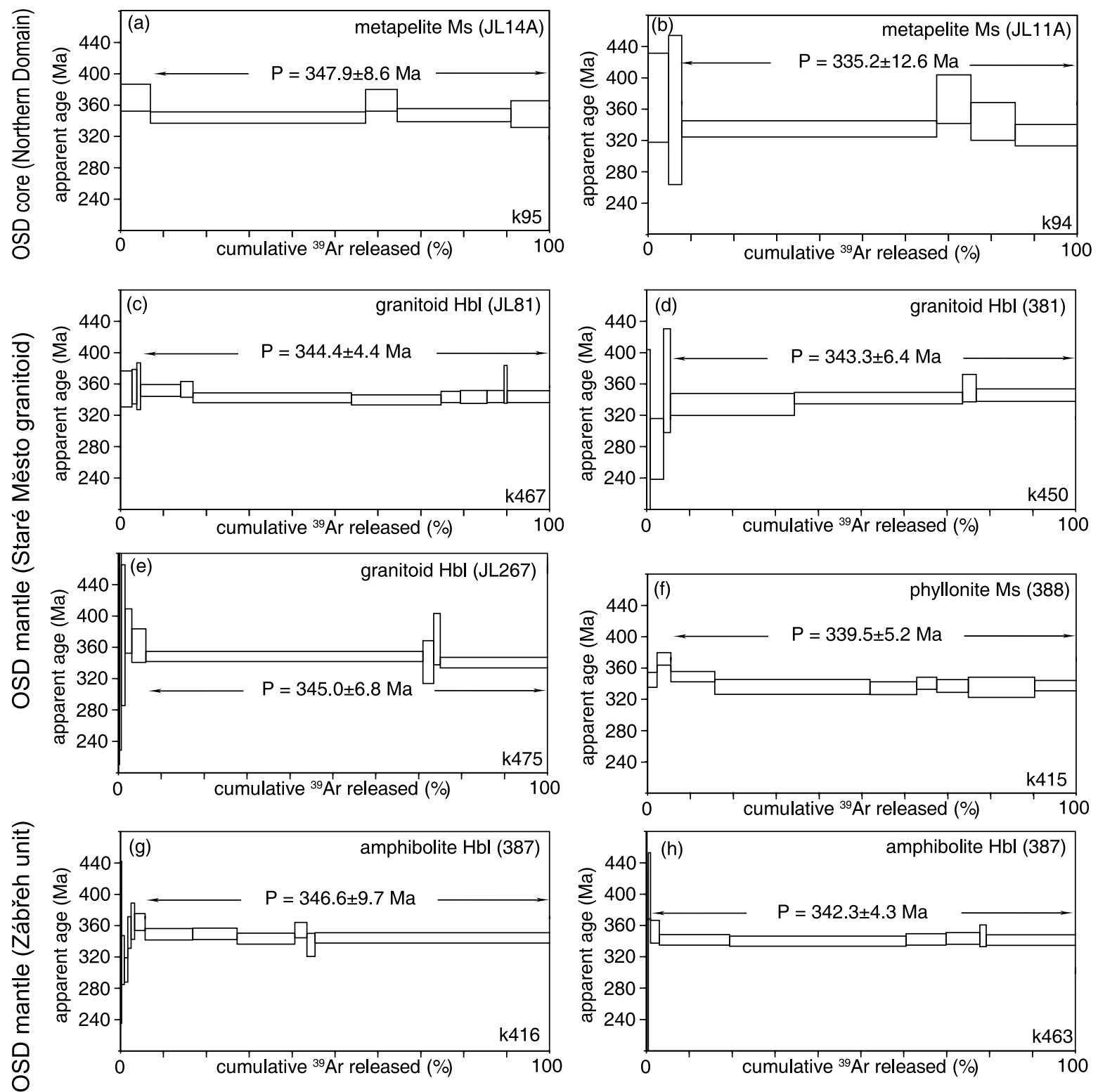

Figure 5. The ${ }^{40} \mathrm{Ar} /{ }^{39} \mathrm{Ar}$ age spectra as a function of released ${ }^{39} \mathrm{Ar}$ on muscovite (Ms) and hornblende (Hbl) single grains for samples from $(a, b)$ the OSD core, $(c-e)$ the Nové Město and Zábřeh OSD mantle units, and $(\mathrm{f}-\mathrm{h})$ the OSD mantle Staré Město unit. Rock type and analyzed mineral are given together with the sample number (in brackets) and the analytical reference (bottom right-hand side,; see Tables S2-S9). Location of the samples is shown in Figure 4 (stars). The error boxes for each step and for the plateau ages are at the $2 \sigma$ level, and the MSWD for plateau ages is indicated. Ages were calculated using the ArArCalc program [Koppers, 2002].

Figure 4. Compilation of geochronological data for the OSD. Probability curves of age data for (a) protolith and metamorphic zircon ages from orthogneiss of the OSD core, (b) Variscan metamorphic zircon ages from eclogites, granulites and neighboring orthogneisses of the OSD core, and (c) ${ }^{40} \mathrm{Ar} /{ }^{39} \mathrm{Ar}$ ages across the OSD core and mantle. (d) Map showing new and earlier reported geochronological data. Metamorphic zircon ages (diamonds), earlier reported (ellipses) and new (stars) ${ }^{40} \mathrm{Ar} /{ }^{39} \mathrm{Ar}$ cooling ages are highlighted. Domains A, B and C are distinguished according to the spatial distribution of ${ }^{40} \mathrm{Ar} /{ }^{39} \mathrm{Ar}$ cooling ages. Mineral abbreviations follow IUGS recommendations after Kretz [1983]. References for the map are (1) Steltenpohl et al. [1993],(2) Schneider et al. [2006], (3) Maluski et al. [1995], (4) Białek and Werner [2004], (5) Bröcker et al. [2009], (6) Anczkiewicz et al. [2007], and (7) Marheine et al. [2002] for the ${ }^{40} \mathrm{Ar}{ }^{39} \mathrm{Ar}$ ages and (1) Żelaźniewicz et al. [2006], (2) unpublished data by Kröner in the work of Białek and Werner [2004], (3) Turniak et al. [2000], (4) Bröcker et al. [2010], (5) Bröcker et al. [2009], (6) Lange et al. [2005b], (7) Štípská et al. [2004], (8) Parry et al. [1997], and (9) Anczkiewicz et al. [2007] and Lange et al. [2005a] for the metamorphic zircon ages. 


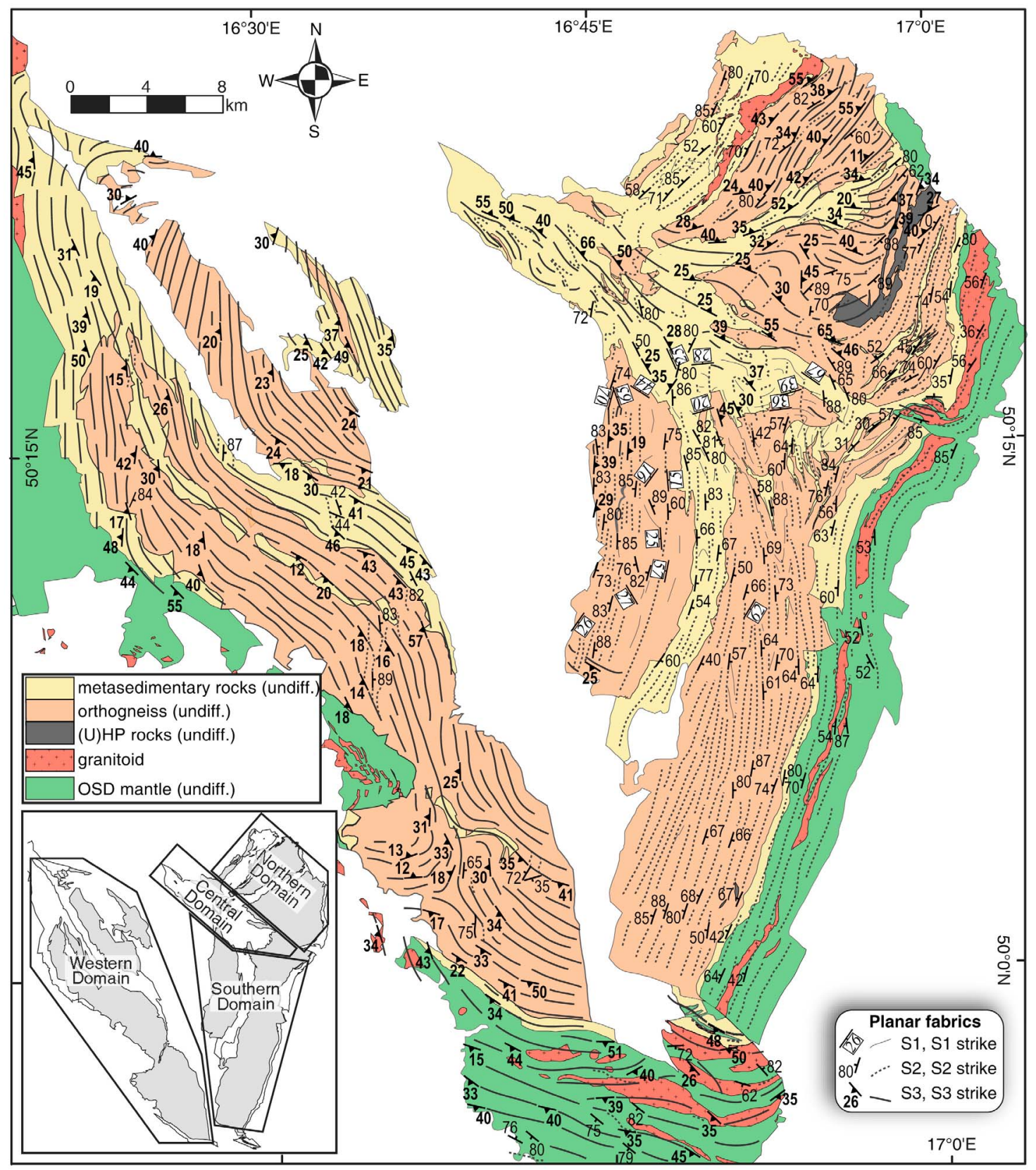

Figure 6. Structural map of planar structures in the OSD showing the distribution and relationships between the early subhorizontal S1, the subvertical S2, and the subhorizontal S3 planar fabrics. Inset shows the position of the different structural domains.

adjacent granitoid [Biatek and Werner, 2004]. The time span between 350 and $340 \mathrm{Ma}$ is therefore taken as a good estimate of cooling below $350-400^{\circ} \mathrm{C}$ in metasedimentary rocks.

[16] A detailed inspection of the spatial distribution of ${ }^{40} \mathrm{Ar} /{ }^{39} \mathrm{Ar}$ data shows that the internal part of the OSD can be divided into three distinct age domains (Figure 4d). The first domain (A) occupies the central and northwestern parts of the OSD and preserves maximum ${ }^{40} \mathrm{Ar} /{ }^{39} \mathrm{Ar}$ cooling ages on hornblende, biotite and muscovite between 350-340 Ma. The second domain (B) corresponds to migmatitic and granulitic rocks exposed in the eastern part of the OSD core and commonly shows younger cooling ages of 340-330 Ma.
The last domain $(\mathrm{C})$ covers the western flank of the OSD and it is characterized by 340-330 Ma cooling ages.

\section{2. ${ }^{40} \mathrm{Ar} /{ }^{39} \mathrm{Ar}$ Geochronology of the OSD Mantle Units}

[17] For the eastern OSD mantle units, three samples were collected in the northern (JL81) and central parts (JL267, 381) of the Staré Město granodiorite intrusion (Figure 4d). They all correspond to a coarse-grained granodiorite composed of plagioclase, quartz, K-feldspar, biotite and hornblende. They preserve a magmatic to solid-state structure which is defined by the orientation of individual hornblende and biotite minerals as well as continuous aggregates of quartz; this structure is concordant with the foliation developed 


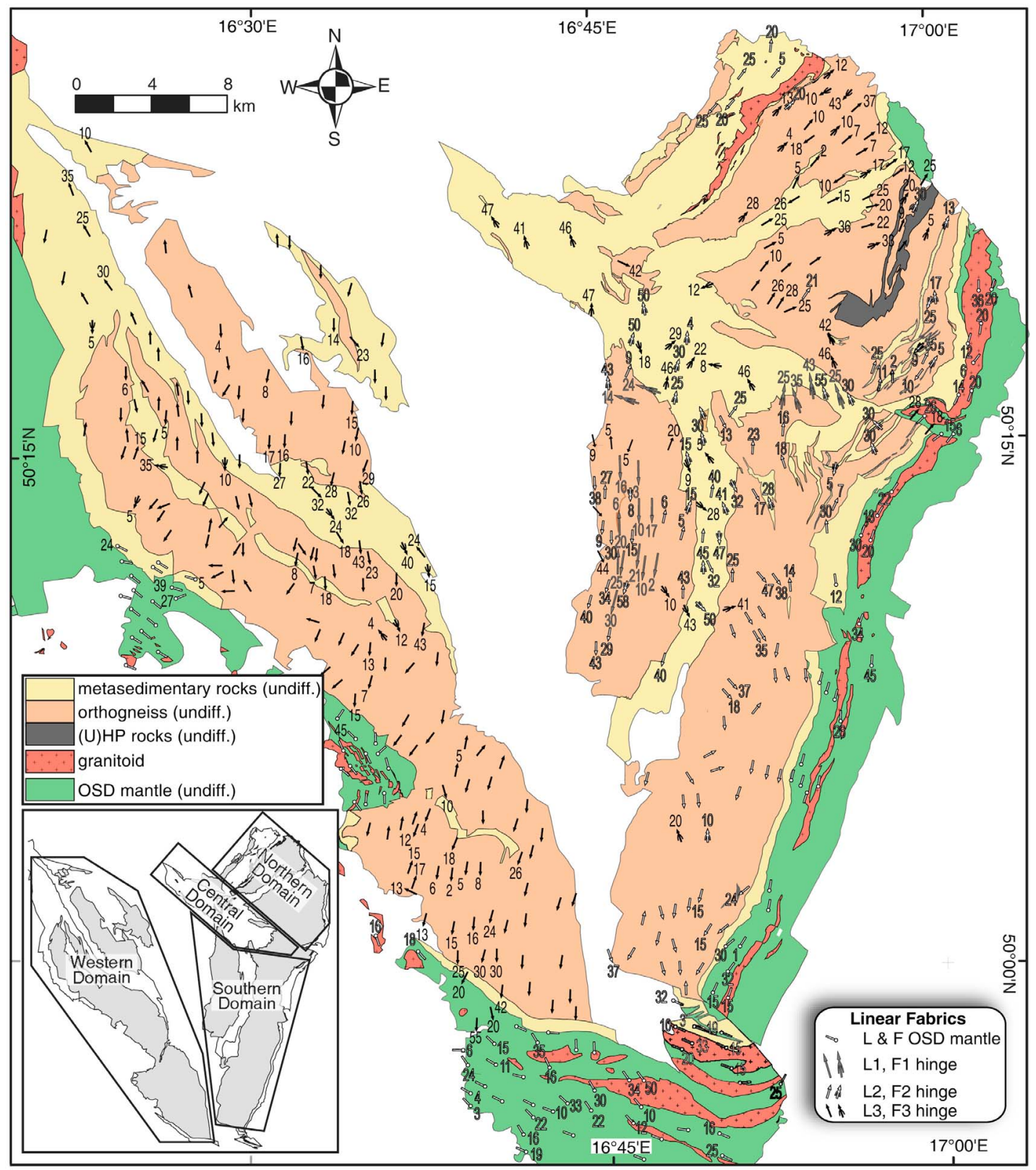

Figure 7. Structural map of linear structures (lineations and fold hinges) in the OSD. Lineations without dip are after Fajst [1976] and Přikryl et al. [1996]. Lineations in the Zábřeh and Staré Město units are after Lehmann [2009]. Inset shows the position of the different structural domains.

in the neighboring OSD orthogneiss [Štípská et al., 2001]. The samples gave hornblende plateau ages of $344.4 \pm 4.4 \mathrm{Ma}$ (JL81), $343.3 \pm 6.4 \mathrm{Ma}(381)$ and $345.0 \pm 6.8 \mathrm{Ma}(\mathrm{JL} 267)$ (Figure 5). Theses ages are similar to the 345-340 Ma magmatic zircon ages obtained in the whole granitoid body [Parry et al., 1997; Śtipská et al., 2004], suggesting that this time span reflects crystallization and cooling below the hornblende closure temperature $\left(450-500^{\circ} \mathrm{C}\right)$ for the Ar system. Further cooling below the biotite closure temperature $\left(\sim 300^{\circ} \mathrm{C}\right)$ is documented by the slightly younger age of $338.2 \pm 0.5 \mathrm{Ma}$ reported for a migmatitic gneiss intruded by the granodiorite sill [Schneider et al., 2006].

[18] For the southern part of the OSD mantle units, two samples from the Zábřeh unit provided new plateau ages.
Sample 388 was collected at the boundary zone between the southern part of the OSD and the Zábřeh unit (Figure 4a). It corresponds to a highly sheared mylonitic amphibolite which shows a penetrative subhorizontal foliation with numerous shear bands, and consists of fine grained amphibole, recrystallized plagioclase and biotite. ${ }^{40} \mathrm{Ar} /{ }^{39} \mathrm{Ar}$ dating gave a hornblende plateau age of $339.5 \pm 5.2 \mathrm{Ma}$ (Figure 5). In addition, a coarse-grained amphibolite (sample 387, Figure 4a) from the northern part of the Zábřeh unit yielded two hornblende plateau ages of $346 \pm 9.7$ and $342 \pm 4.3 \mathrm{Ma}$ (Figure 5).

[19] $\mathrm{The}{ }^{40} \mathrm{Ar} /{ }^{39} \mathrm{Ar}$ study across the whole OSD allows definition of a fourth cooling age domain (Figure 4). This domain corresponds to the OSD mantle units which show 

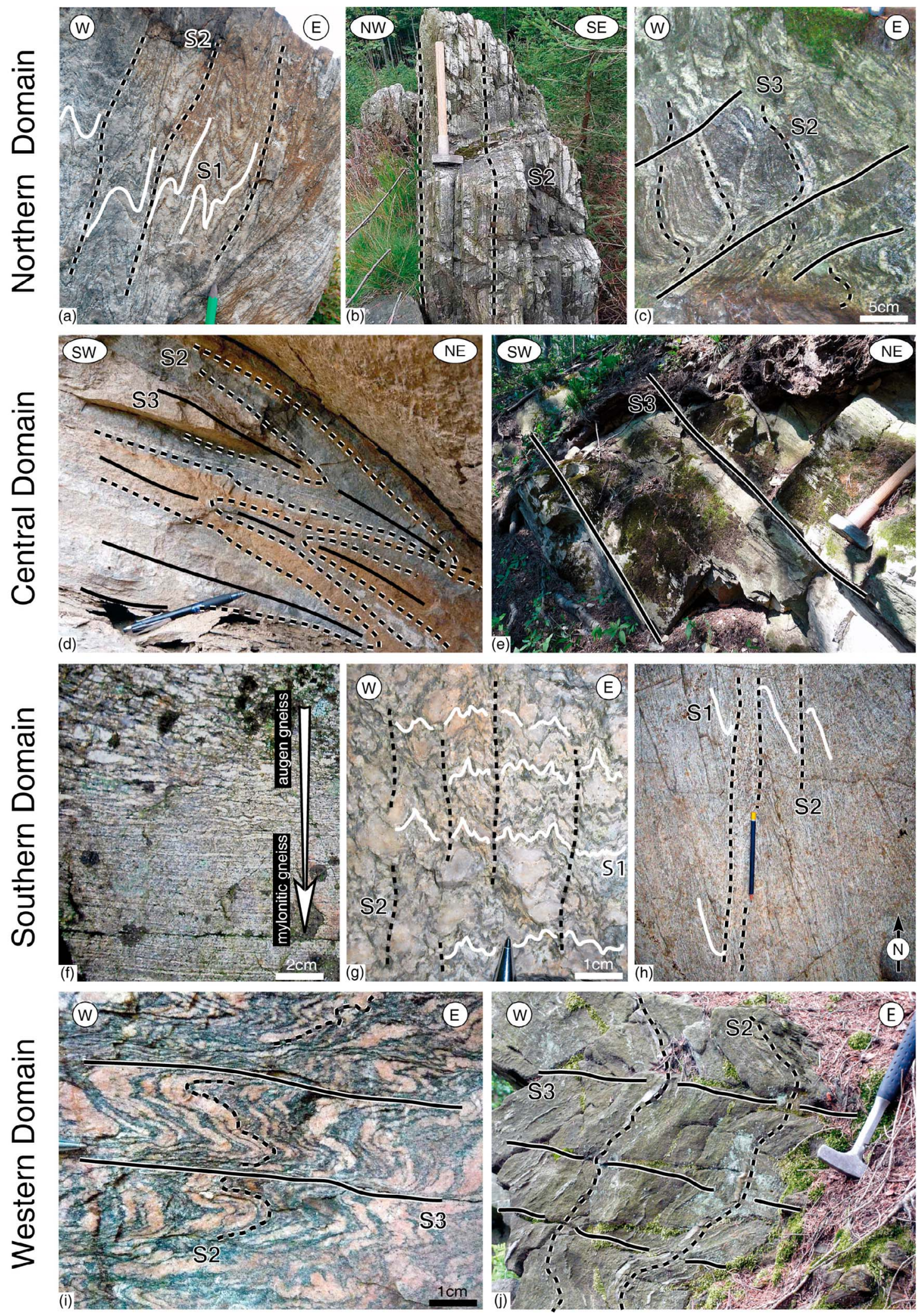

Figure 8 
cooling ages that are systematically older compared with the neighboring domains (B and $\mathrm{C}$ ) of the OSD core, but similar to the 350-340 Ma ages obtained in the central domain of the OSD core (A).

\section{Structural Evolution}

[20] Three main deformation events (D1, D2 and D3) of variable intensity and geometry are developed in the OSD (Figures 6, 7, 8, and 9). In all structural levels, the early D1 deformation is responsible for the formation of a rarely preserved subhorizontal foliation. The subsequent D2 deformation produces $\mathrm{N}-\mathrm{S}$ and NE-SW trending antiforms with cores of highly deformed orthogneiss and (U)HP rocks alternating with synforms composed of metasedimentary rocks of the Stronie and Młynowiec formations. This D2 event generates either a subvertical axial planar cleavage or a new continuous foliation. The last D3 deformation is associated with the development of recumbent folds affecting both the $\mathrm{S} 1$ relicts and the $\mathrm{S} 2$ foliation. The heterogeneous character of the D1, D2 and D3 deformation events led to the subdivision of the OSD into four structural domains (Figure 2, inset). The Northern Domain covers the Góry Złote (Rychlebské Hory) Mountains, the Central Domain is represented by the Krowiarki mountain range, the Southern Domain covers the Králíky-Śnieżnik massif, and the Western Domain encompasses the Góry Bystrzyckie and the Orlické Hory Mountains (Figure 2). The geometrical and kinematic relationships between these domains and the surrounding OSD mantle units have also been investigated.

\subsection{Northern Domain (Góry Zlote massif)}

[21] The Northern Domain consists of two synforms of metasedimentary rocks alternating with two orthogneiss antiforms [Don, 1964; Dumicz, 1979; Śtipská et al., 2004, Skrzypek et al., 2011a], one of which preserves a core of HP granulite (Figures 6 and 9a). The NW synform is composed of metapelite and felsic metavolcanite, and is intruded along its SE boundary by the Carboniferous Jawornik granitic body. In the synform, the rare subhorizontal S1 metamorphic foliation is commonly affected by moderate to tight upright F2 folds (Figure 8a) leading to the development of a subvertical S2 cleavage which is dominant in the area (Figures 6, 8b, and 9a). The subsequent D3 overprint only locally reworked the $\mathrm{S} 2$ foliation into open and recumbent F3 folds with an S3 axial plane cleavage gently to moderately dipping to the NW (Figure 9a). The magmatic and solid-state structures in the adjacent granitoid are similar in orientation to the S2 fabric in the metapelite, and are moderately reworked by the D3 deformation.

[22] Toward the SE, the synform adjoins an antiform that is cored by the migmatitic and mylonitic Gierałtow orthogneiss and mantled by the Śnieżnik augen orthogneiss. There, the subvertical S2 gneissosity is characterized by intense flattening of K-feldspar megacrysts in the augen orthogneiss variety and by a stromatitic layering and schlieren in the migmatitic orthogneiss. The S2 foliation is intensely transposed into a S3 crenulation cleavage or a new dominant S3 metamorphic foliation. The D3 deformation progressively increases toward the SE and is also dominant in the adjacent metasedimentary synform (Figures 6 and 9a). There, the subvertical S2 foliation is only preserved in the amphibolite, marble and quartzitic schist intercalations, whereas it is deformed by close to isoclinal F3 folds with a subhorizontal S3 axial plane cleavage in mica schist. More commonly, the metapelitic lithologies show a continuous S3 metamorphic schistosity that is moderately dipping toward the NW or SE (Figure 6).

[23] The SE gneissic antiform hosts a narrow core of granulite surrounded by migmatite and augen to banded orthogneiss. Within the granulite belt, folded relicts of the probably subhorizontal S1 layering are documented by alternating mafic and felsic layers [Śtípská et al., 2004]. In addition, relicts of the S1 migmatitic fabric were identified at the SE border of the granulite belt suggesting that the D1 event was already associated with partial melting (Figure 8a). In the migmatite the S1 fabric is generally transposed into the subvertical NE-SW striking S2 foliation which is still coeval with partial melting (Figures 6 and 8c). The D2 structures are in turn heterogeneously reworked by recumbent F3 folds and gently dipping amphibolite-facies S3 foliations that are frequently injected by granitic melt (Figure $8 \mathrm{c}$ ). The axial planes of the F3 folds are dipping in opposite directions on both sides of the granulitic core, thereby forming a fan-like structure around the granulite belt (Figures 6 and 9). Across the whole Northern Domain, the dominant linear structure corresponds to the intersection between the S2 and S3 fabrics and is represented by a strong NE-SW trending subhorizontal L3 lineation which is parallel to the hinges of F3 folds (Figure 7).

\subsection{Central Domain (Krowiarki Mountains)}

[24] In the Central Domain, a prominent structure in the metasedimentary rocks of the Stronie and Młynowiec formations is a subhorizontal to moderately dipping S3 foliation (Figure 6). This fabric consistently dips to the NE and is

Figure 8. Field photographs showing deformation structures in the Northern, Central, Southern and Western Domains.
(a) Subvertical S2 cleavage with relicts of the S1 migmatitic fabric (E of the granulite belt, Kresowy stream, $1400 \mathrm{~m}$ NW
of Bielice). (b) Penetrative subvertical S2 mylonitic fabric (Skrzynka-Złoty Stok area, $800 \mathrm{~m}$ WN of the Jawornik Wielki
hill). (c) S2 stromatitic fabric slightly reworked by D3. New leucosomes are injected in the axial plane of F3 fold (close to
Črvený Důl, $750 \mathrm{~m}$ E of the granulite belt). (d) Tight recumbent F3 fold in marble (Mt Krzyżnik quarry, $1600 \mathrm{~m}$ SSW of
Stronie Sląskie). (e) Moderately NE dipping S3 foliation in metapelite ( $2000 \mathrm{~m}$ SE of Żelazno). (f) Gradual transition from
augen to banded/mylonitic orthogneiss (Międzygórze, $500 \mathrm{~m}$ E of the eclogite). (g) Early subhorizontal planar fabric slightly
reworked by the subvertical S2 cleavage in augen orthogneiss (Goworówka stream, $3300 \mathrm{~m}$ E of Goworówka). (h) Relicts of
the S1 stromatitic fabric transposed into the subvertical S2 migmatitic cleavage (Malá Morava stream, $1500 \mathrm{~m}$ N of Sklené).
(i) Open F3 fold affecting the subvertical S2 fabric in metapelite ( $600 \mathrm{~m}$ N of Neratov). (j) Stromatitic to phlebitic S2
migmatite moderately transposed into the S3 subhorizontal fabric (Zemská Brána, $3600 \mathrm{~m}$ NE of Klášterec nad Orlicí). 

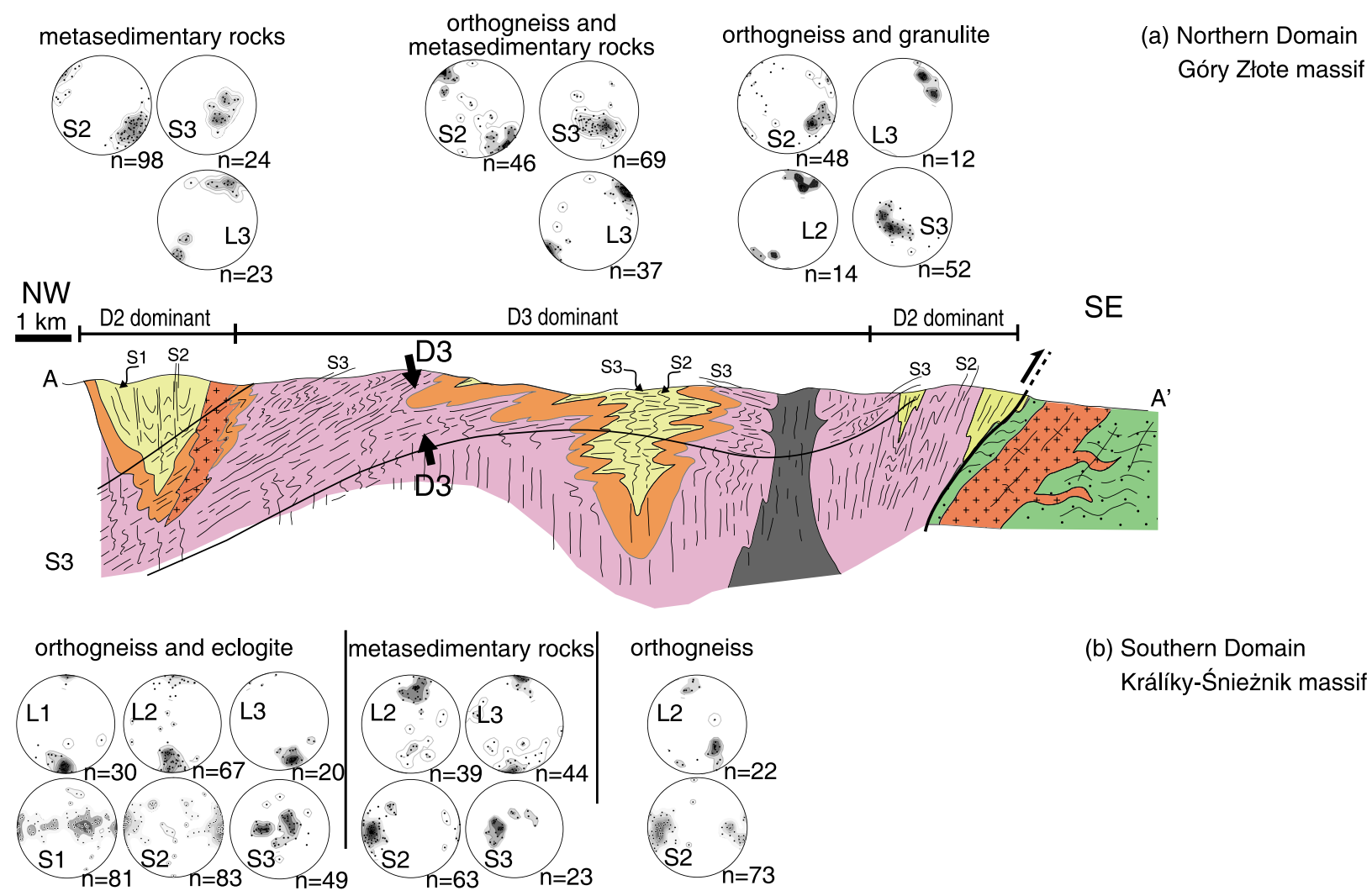

(b) Southern Domain Králíky-Śnieżnik massif
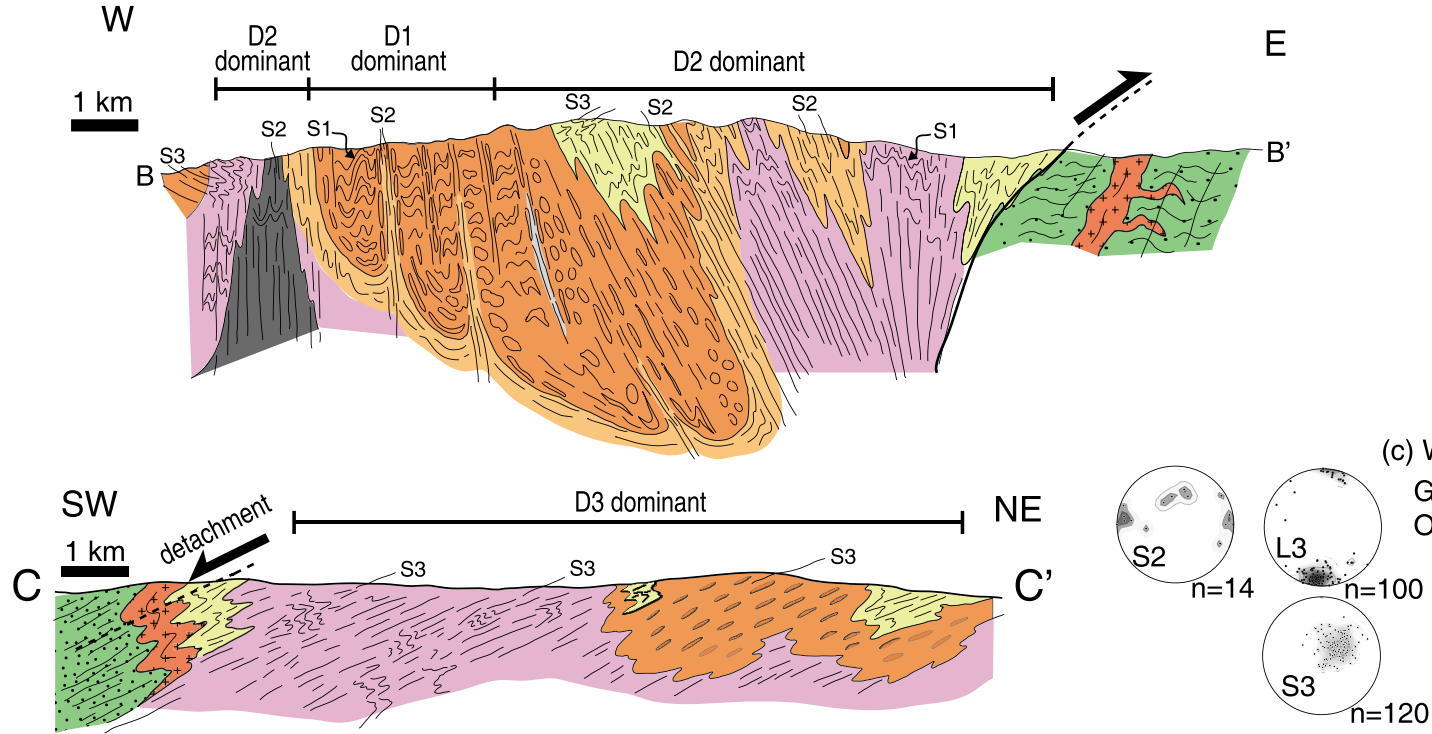

(c) Western Domain Góry Bystrzyckie and Orlické Hory massifs

\begin{tabular}{|c|c|c|}
\hline OSD mantle & OSD core & \\
\hline$\therefore \quad$ Nové Město unit & metasedimentary rocks & migmatitic orthogneiss \\
\hline $\begin{array}{l}\text { L. S Staré Město unit } \\
++^{+}++^{+} \text {granitoid }\end{array}$ & $\begin{array}{l}\text { banded to augen orthogneiss } \\
\text { mylonitic orthogneiss }\end{array}$ & nulite, eclogite \\
\hline
\end{tabular}

Figure 9. Interpretative geological cross sections through (a) the Northern Domain, (b) the Southern Domain, and (c) the Western Domain (see Figure 2 for location). Orientation diagrams show equal-area, lower-hemisphere projections of planar and linear structures. The subhorizontal planar structures within the Staré Město unit represent the compositional banding of layered amphibolite developed during MidLate Cambrian extension [Štípská et al., 2001]. 

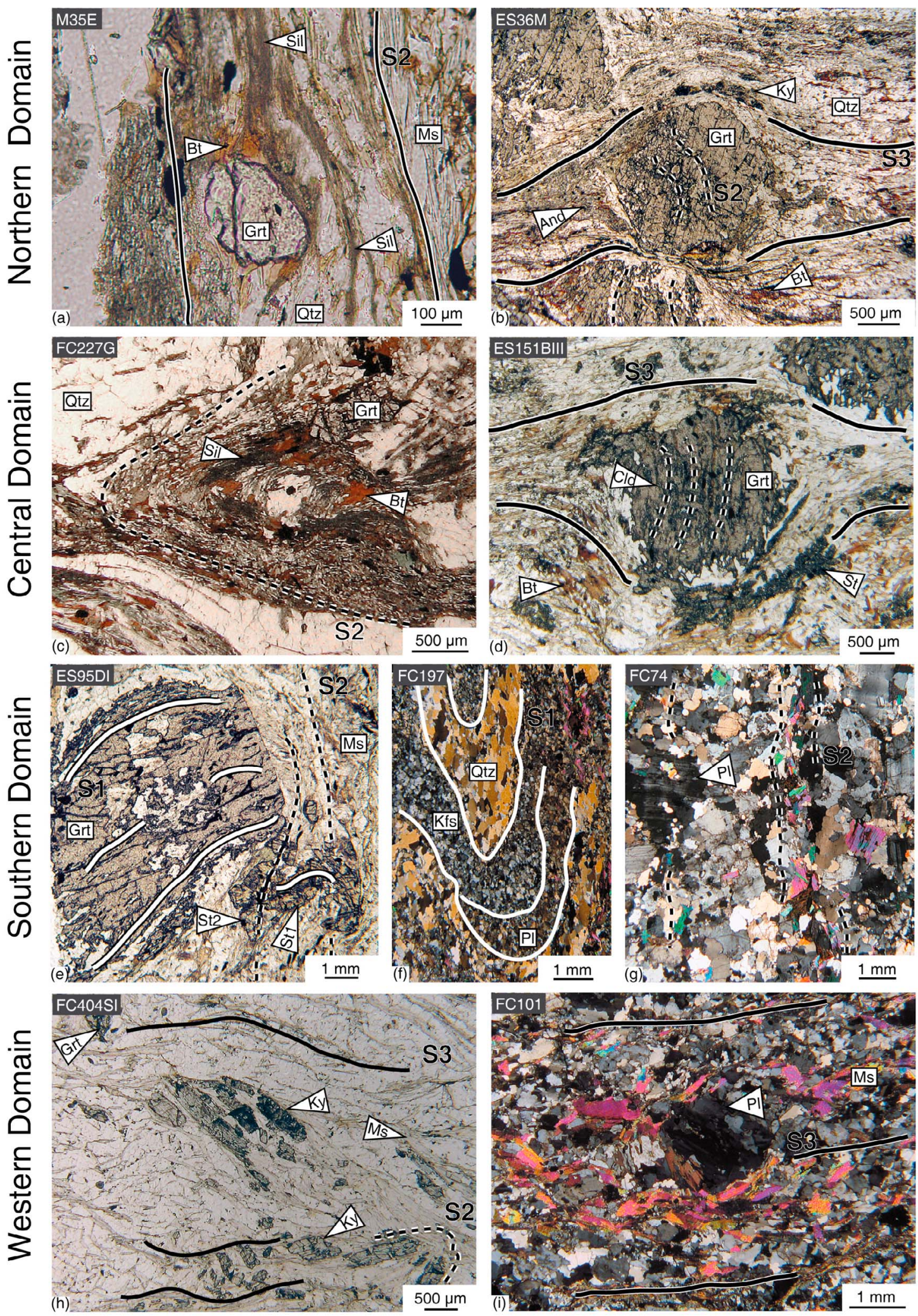

Figure 10 
parallel to the axial planes of the tight to isoclinal, NW-SE trending F3 folds (Figures 8d and 8e). The earlier S2 foliation is rarely preserved as steeply to moderately $\mathrm{W}$ or $\mathrm{NW}$ dipping planes, the trend of which is nearly continuous either with the NE-SW striking S2 fabric in the northern domain, or with the $\mathrm{N}-\mathrm{S}$ striking $\mathrm{S} 2$ foliation in the southern domain (Figure 6). In the easternmost part of the Central Domain, the structural record in the Młynowiec formation and the adjacent migmatitic gneiss is characterized by the absence of D3 overprint, leaving the D1 and D2 structures well preserved. In some places the D1 deformation produced a weak cleavage refracted in relicts of the original sedimentary bedding, but more commonly led to the development of the shallowly NE dipping S1 foliation (Figure 6). The D2 deformation is manifested by the upright to moderately inclined, close to tight F2 folds affecting the D1 structures.

\subsection{Southern Domain (Králíky-Śnieżnik Massif)}

[25] The Międzygórze antiform [Don, 1964, 1982; Štípská et al., 2012] is formed by orthogneiss cored by a N-S trending belt of eclogite lenses (Figure 2). In the stromatitic to nebulitic migmatite to the west of the eclogite, the earliest $\mathrm{S} 1$ foliation is pervasively transposed into the subvertical S2 migmatitic foliation which is in turn heterogeneously reworked by the moderately $\mathrm{E}$ dipping $\mathrm{S} 3$ mylonitic to migmatitic cleavage (Figures 6 and 9b). To the east of the eclogite, the D1 structures are almost unaffected by later deformation phases (Figures 6 and 9b). Consequently, it is the only area in the OSD where the geometry and kinematics of the deep-seated D1 tectonites can be investigated in detail. Here, low-strain augen orthogneiss is progressively (at a meter scale) transformed into a banded to mylonitic orthogneiss [Lange et al., 2002; Chopin et al., 2012], displaying a subhorizontal foliation and a $\mathrm{N}-\mathrm{S}$ trending mineral lineation defined by elongated K-feldspar megacrysts (Figures 7 and $8 \mathrm{f}$ ). The augen orthogneiss preserves well-developed sigma clasts and $\mathrm{N}$ dipping shear bands that indicate a top to the $\mathrm{N}$ sense of shear. These rocks also show close to isoclinal folds that locally evolve to highly non-cylindrical sheath folds with N-S oriented noses [see also Štipská et al., 2012]. The subsequent D2 deformation is manifested by asymmetrical $\mathrm{m}$ - to $\mathrm{km}$-scale open upright folding associated with the $\mathrm{N}-\mathrm{S}$ striking subvertical S2 crenulation cleavage (Figures $8 \mathrm{~g}$ and $9 \mathrm{~b}$ ), and leads to the development of a second generation of mylonitic orthogneiss. The S2 foliation is only rarely affected by close to isoclinal, gently inclined to recumbent F3 folds.
[26] Further east, the D1 dominated structural domain is juxtaposed with a steeply inclined E vergent Sienna synform [Don, 1982; Śtípská et al., 2012] composed of the Stronie metasedimentary rocks (Figures 6 and $9 \mathrm{~b}$ ). Here, the wellpreserved penetrative $\mathrm{S} 1$ metamorphic fabric is deformed by close to isoclinal, similar F2 upright folds, and is progressively transposed into a new N-S striking S2 metamorphic foliation (Figure $8 \mathrm{~g}$ ). The $\mathrm{F} 2$ fold hinges are gently to moderately plunging either to the $\mathrm{N}$ or to the $\mathrm{S}$ (Figure 7) suggesting a variable dip of the $\mathrm{S} 1$ foliation prior to the $\mathrm{D} 2$ deformation. Consequently, it is proposed that the S1 foliation was affected by moderate $\mathrm{E}-\mathrm{W}$ folding before $\mathrm{D} 2$ deformation. A weakly developed F3 recumbent folding event produces a rare subhorizontal S3 axial plane cleavage and typical mullion structures that are parallel to the N-S trending L3 intersection lineation (Figure 7).

[27] In the eastern Králíky-Śnieżnik antiform [Don, 1982; Śtípská et al., 2012], augen and banded orthogneiss and migmatite are exposed. As with the neighboring synform, a dominant foliation is represented by the $\mathrm{N}-\mathrm{S}$ subvertical S2 foliation (Figures 6 and 9b) showing a gradient from augen/ophtalmic to nebulitic migmatite via stromatitic varieties. These textural variations are commonly associated with the injection of granitic melt parallel to the S2 foliation (Figure 8h). The N-S S2 foliation bears a weak subhorizontal to moderately S or SE plunging mineral lineation (Figure 7) and forms an upright structural fan (Figure 9b).

\subsection{Western Domain (Góry Bystrzyckie and Orlické Hory Massifs)}

[28] Like in other structural domains, alternating orthogneiss and metapelite belts are exposed in the Western Domain [Dumicz, 1964] (Figure 2). A dominant fabric is represented by the gently to moderately W to SSW dipping S3 foliation, the strike of which is parallel to the lithological boundaries (Figure 6). In the augen orthogneiss, the S3 subhorizontal foliation is generally present and rarely evolves to a banded orthogneiss variety. This foliation bears a strong lineation plunging gently to moderately to the $\mathrm{S}$ (Figure 7). In these rocks, rare relicts of the N-S striking subvertical S2 foliation are preserved (Figure 8i). In metapelite, the dominant structure is the penetrative $\mathrm{S} 3$ foliation, but remnants of the former metamorphic layering S2 can be observed. Indeed, the S3 foliation results from open to tight F3 folding (Figure 8j) of the originally subvertical S2 fabric. In places where migmatite dominates, the gradual transitions from augen orthogneiss to mylonitic or nebulitic

\footnotetext{
Figure 10. Photomicrographs illustrating the relationships between metamorphic minerals and microstructures in the metapelite and orthogneiss from the Northern, Central, Southern and Western domains. (a) Sillimanite-garnet assemblage parallel to the S2 cleavage (Skrzynka-Złoty Stok area, Muflon hill). (b) Garnet with inclusion trails oblique to the external S3 foliation, kyanite relicts and andalusite in garnet pressure shadows (Zálesí). (c) Sillimanite and garnet parallel to the S2 foliation affected by tight F3 microfolds (Wapnisko hill, $3700 \mathrm{~m}$ E of Stronie Sląskie). (d) Garnet with inclusion trails (chloritoid and ilmenite) oblique to the external S3 foliation. A microfolded staurolite aggretate is visible in the matrix (Janowiec hill, $3300 \mathrm{~m}$ SSW of Stronie Ślaskie). (e) Garnet with inclusion trails oblique to the external S2 foliation. Two generations of staurolite are visible (Mariańskie Skały, $4600 \mathrm{~m}$ ESE of Międzygórze). (f) Laminated orthogneiss reworked by tight F2 microfold (Goworówka stream, $3300 \mathrm{~m}$ E of Goworówka town). (g) S2 nebulitic fabric in migmatite (Morava stream, S of Malá Morava). (h) Elongated kyanite crystals oblique to the $\mathrm{S} 3$ foliation (Vrchní Orlice, $3000 \mathrm{~m} \mathrm{~S}$ of Neratov). (i) Plagioclase porphyroclast surrounded by the S3 migmatitic matrix (Jablonné nad Orlicí). (Figures 10a-10e and 10h show plane-polarized light and Figures 10f, 10g, and 10i show crossed polars.
} 
migmatite are common in isoclinally folded relicts of the S2 foliation. The recumbent F3 folds show a S3 cleavage associated with axial planar leucosomes (Figure 8j). These folds affect already partially molten orthogneiss and form a N-S trending L3 lineation (Figure 7). Přikryl et al. [1996] also recognized this $\mathrm{N}-\mathrm{S}$ trending linear fabric that is marked by elongated quartz aggregates recrystallized at low to middle temperature conditions. In contrast, a gently to moderately ESE plunging lineation defined by recrystallized $\mathrm{K}$-feldspar grains is thought to reflect a higher temperature deformation event [Prikryl et al., 1996; Murtezi, 2006].

\subsection{Structural Record in the OSD Metamorphic Mantle Units}

[29] The Nové Město and Zábřeh mantle units reveal a polyphase structural evolution. The earliest structure is a dominant $\mathrm{S} 1$ foliation which is parallel to the margin of the OSD core. In the Nové Město unit, this greenschistfacies fabric is associated with kinematic indicators suggesting early top to the ESE sense of shear [Aleksandrowski and Mazur, 2002; Mazur et al., 2005]. At the boundary between the OSD core and mantle, evidences for NNW-SSE ductile dextral strike-slip followed by Late CarboniferousEarly Permian (?) semi-brittle, SSW-directed normal displacement have been proposed by Mazur et al. [2005]. Both units show an intense reworking by a gently W to SW dipping S3 cleavage which is progressively passing to a mylonitic S3 fabric toward the boundary with the OSD core. Close to this boundary, numerous shear criteria indicating top to the SW normal displacement have been described by Mazur et al. [2005]. A very characteristic feature of the OSD mantle units is a mineral and intersection lineation which lies at a high angle to the lineations preserved in the OSD core (Figure 7). The existence of almost perpendicular linear fabrics between the OSD core and mantle units has already been interpreted as a "structural unconformity" reflecting different modes of emplacement of the gneissic core and its metasedimentary mantle units [Pauk, 1953; Fajst, 1976]. This L3 lineation is also well developed in the southern granodiorite sills that preserve a strong NW-SE trending constrictional fabric interpreted as a result of superimposed deformations [Lehmann, 2009].

[30] In the Staré Město unit, the oldest fabric is subhorizontal and is attributed to a Cambro-Ordovician event that occurred at granulite- to amphibolite-facies conditions [Lexa et al., 2005]. A Variscan deformation event later affected this fabric and produced upright NNE-SSW trending folds, shear zones and a penetrative amphibolite-facies S2 foliation. This deformation operated along the whole eastern margin of the OSD at pressure conditions of 8-10 kbar [Stipská et al., 2004; Baratoux et al., 2005; Lexa et al., 2005].

[31] Toward the Carboniferous granitoid sill, the S2 fabric becomes more penetrative and is associated with high temperature recrystallization processes [Baratoux et al., 2005]. Because the syntectonic granitoid intrusion has been dated at c. $340 \mathrm{Ma}$, this D2 deformation is considered as Carboniferous in age [Parry et al., 1997; Śtípská et al., 2001]. Numerous shear indicators developed in the metagabbro and in the progressively cooled granitoid suggest that the D2 deformation developed during dextral transpression parallel to the OSD margin. The D3 deformation is manifested by greenschist-facies dextral shear zones that are believed to be kinematically linked with the D2 high temperature shearing [Štípská et al., 2001].

\section{Deformation and Metamorphism}

[32] In several metapelitic belts of the OSD core, crystallizationdeformation relationships have been examined in order to link the growth of metamorphic minerals with the successive macroscopic fabrics described above (Figure 10). A spatial correlation of all these microstructural observations is then used to reveal the dominant metamorphic regime in distinct areas of the OSD (Figure 11).

\subsection{D1 Parageneses}

[33] Because of the successive tectonic overprints, relicts of the D1 structures are scarce across the OSD (Figure 6). Consequently, the access to metamorphic records associated with this deformation event is restricted to a few samples from the Northern and Southern Domains. In the SE part of the Northern Domain, Skrzypek et al. [2011b] reported prograde garnet growth up to $5 \mathrm{kbar} / 550^{\circ} \mathrm{C}$ in the $\mathrm{S} 1$ fabric. In the NW part of the same domain, the microfolded garnetand staurolite-rich S1 layering indicates that the metamorphic conditions reached the Grt-St stability field in the same foliation (Figure 11a). Similarly, in the Southern Domain microstructural evidences point to the occurrence of a Grt-St assemblage in the S1 fabric (Figure 10e) and led Stípská et al. [2012] to propose a prograde evolution to $\sim 6 \mathrm{kbar} /$ $580^{\circ} \mathrm{C}$ during or after D1 deformation.

\subsection{D2 Parageneses}

[34] Metamorphic minerals associated with the S2 foliation are better observed because this fabric is commonly well-preserved across the OSD. In the Northern Domain, prolonged prograde metamorphism toward the sillimanite stability field in the NW part (Figure 10a) and the kyanite stability field in the SE part (Figure 10b) is observed. In the SE metasedimentary belt, a Grt-St-Ky paragenesis developed parallel to the $\mathrm{S} 2$ fabric was used to propose peak conditions of $\sim 7 \mathrm{kbar} / 630^{\circ} \mathrm{C}$ related to the end of $\mathrm{D} 2$ deformation [Skrzypek et al., 2011a]. Accordingly, peak P-T conditions for the NW belt where staurolite decomposes into the assemblage Grt-Sil-Bt should lie below $\sim 6 \mathrm{kbar}$ at similar temperatures. However, the syn-D2 growth of andalusite also reflects a subsequent pressure decrease during the development of S2 in the NW part.

[35] In the Central Domain, metamorphic minerals parallel to the folded relicts of S2 indicate prograde metamorphism toward variable peak assemblages (Figure 11b). From NW to SE, a Grt-Cld paragenesis is followed by a Grt-Sil one (Figure 10c) and finally by a Grt-St-Ky assemblage. The latter assemblage was observed by Jastrzębski [2009] who proposed that peak conditions of $9-10 \mathrm{kbar} / 510^{\circ} \mathrm{C}$ were achieved during the development of the subvertical S2 fabric. This view is supported by the occurrence of kyanite parallel to the subvertical S2 foliation in a paragneiss of the Młynowiec formation to the east (Figure 11b).

[36] In the Southern Domain, a second generation of both garnet and staurolite (Figure 10e) parallel to S2 indicates prograde metamorphism up to $\sim 7.5 \mathrm{kbar} / 630^{\circ} \mathrm{C}$ in the 

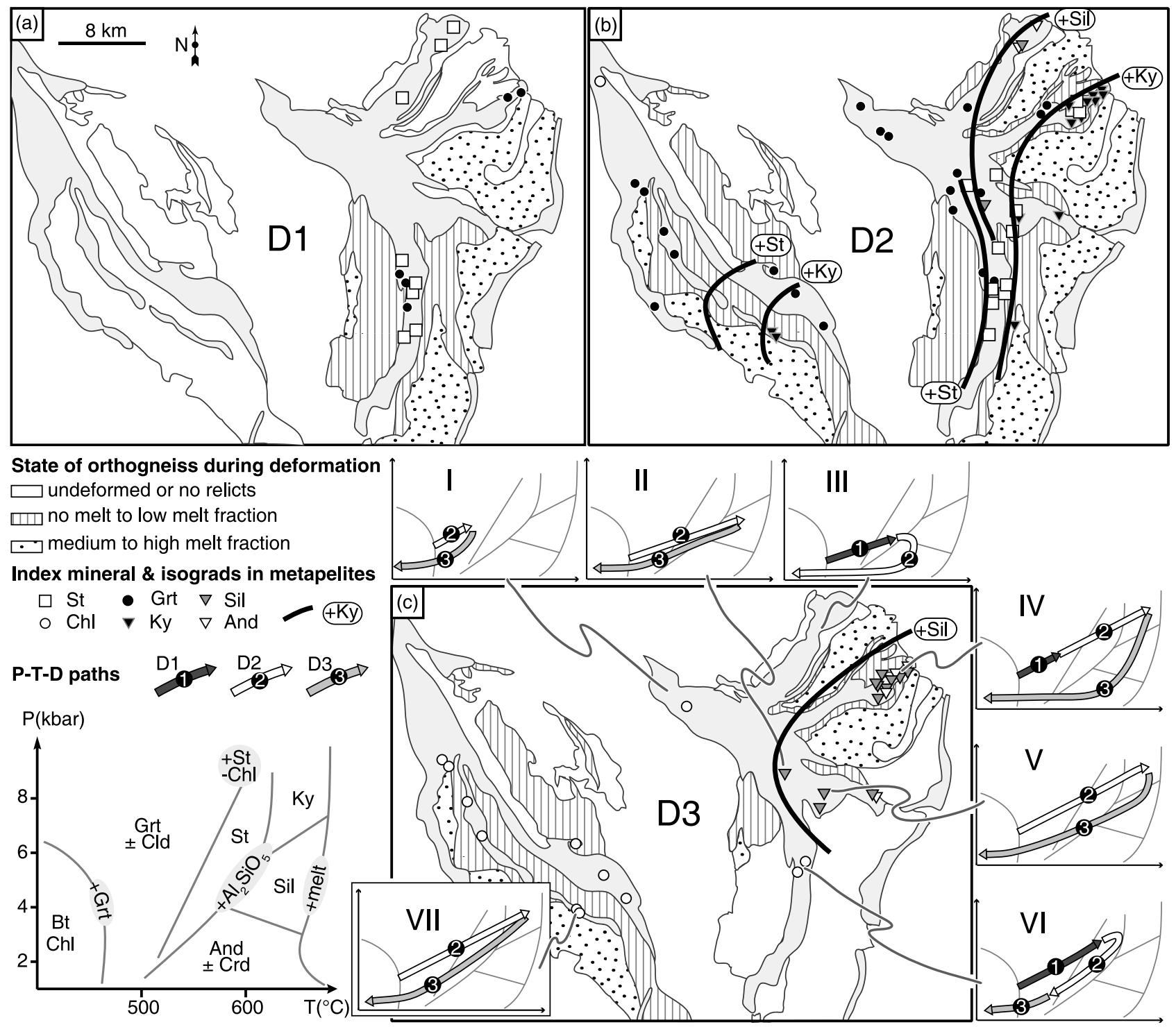

Figure 11. $(\mathrm{a}-\mathrm{c})$ Maps showing the occurrences of metamorphic minerals and the associated isograds in metasedimentary rocks. The state of orthogneissic rocks during the D1, D2 and D3 deformation events is also reported. Insets I to VI show qualitative $\mathrm{P}-\mathrm{T}-\mathrm{D}$ paths deduced from crystallization-deformation relationships in metapelite. Mineral stability fields have been drawn using pseudosections of Skrzypek et al. [2011a, 2011b]. Metamorphic isograds in the Western Orlica Domain are partly drawn after Opletal et al. [1980].

subvertical fabric [Štípská et al., 2012]. However, chlorite blastesis parallel to the S2 foliation suggests that retrograde metamorphism down to $5 \mathrm{kbar} / 500^{\circ} \mathrm{C}$ (Figure 10b) also occurred during this deformation event.

[37] In the Western Domain, Opletal et al. [1980] have reported the occurrence of garnet and staurolite toward the NW. Additional observations indicate that these minerals were formed during the D2 deformation. In the SE part of the Western Domain, garnet with chloritoid inclusions is in equilibrium with staurolite and elongated kyanite in the matrix (Figure 10h). Both garnet inclusion trails and mineral elongation are parallel to the S2 fabric and therefore point to a prograde evolution from the Grt-Cld to the Grt-St-Ky stability field during D2 in this area (Figure 11b).

\subsection{D3 Parageneses}

[38] The heterogeneous D3 overprint has produced wide areas where the growth of metamorphic minerals can be linked with the S3 foliation. In the SE part of the Northern Domain, garnet is resorbed and kyanite is successively replaced by sillimanite and andalusite oriented parallel to the $\mathrm{S} 3$ foliation (Figure 10b). This retrograde evolution was constrained at $2-3 \mathrm{kbar} / 560-620^{\circ} \mathrm{C}$ [Skrzypek et al., 2011a]. In the NW and central parts of the Central Domain, metamorphism associated with the D3 deformation is deduced from chlorite growth after garnet (Figure 11c), while sillimanite replacing staurolite is observed to the SE. The whole Central Domain therefore shows retrograde conditions during D3. In the SE part, Jastrzębski [2009] proposed that 


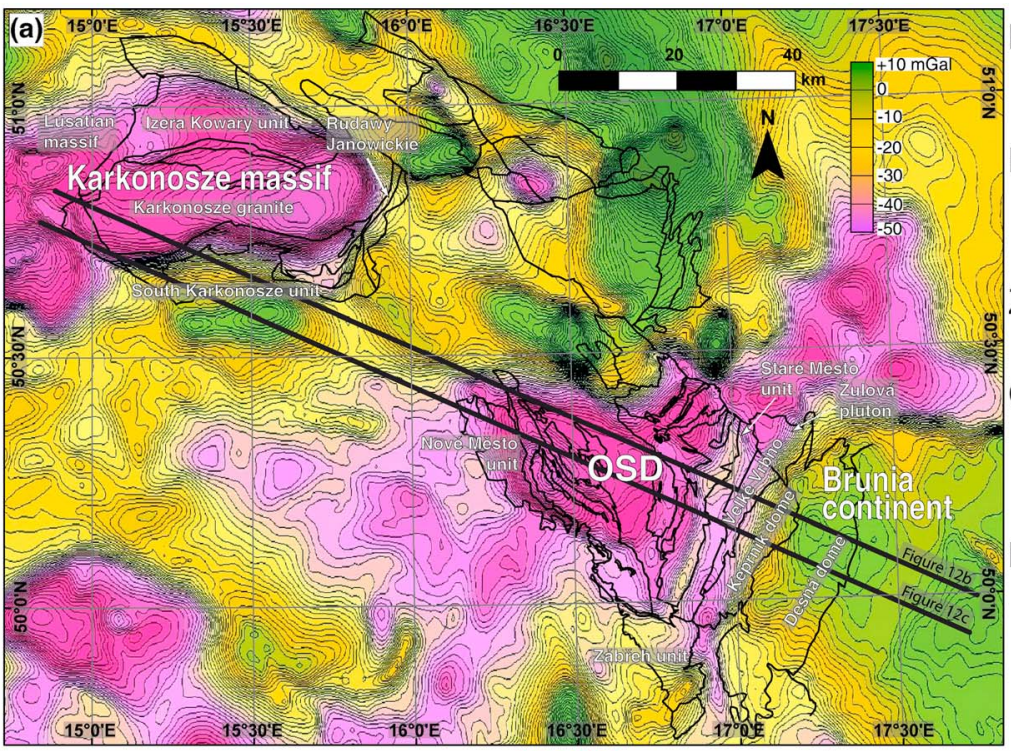

Basin

2.55-2.54 sediments (Culm, Intra-Sudetic basin)

2.83 sediments intruded by basaltic rocks

(Intra-Sudetic basin)

Karkonosze massif

2.90 metabasite with blueschist occurrence

2.90 metasedimentary \& metavolcanic rocks

2.69 orthogneiss

2.80 lower crust

Zábřeh, Nové Město and Staré Město units 2.75 upper crust

2.90 amphibolite, metabasic lower crust

Orlica-Snieżnik dome

$2.7 \quad$ granitoid

2.67 orthogneiss

3.34 eclogite

2.95 granulite

Brunia continent

2.68-2.75 crystalline nappe

2.78 middle crust

2.90 lower crust

2.65 late Variscan granitoid $3.20 \square$ mantle

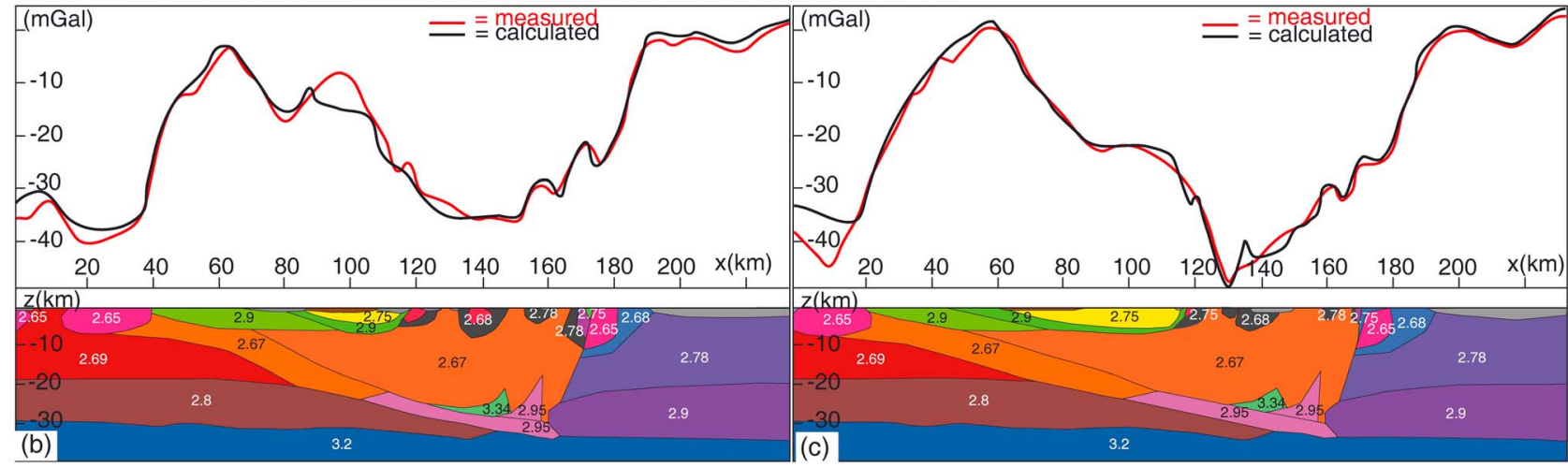

Figure 12. Bouguer anomaly map of the Sudetes and $2 \mathrm{D}$ density modeling profiles. (a) Bouguer anomaly map with main lithological boundaries represented by black lines (see also Figure 1). (b, c) Representative 2D gravity models across the entire Sudetes. The location of each profile is indicated in Figure 12a. Density is expressed in $\mathrm{g} / \mathrm{cm}^{3}$.

it corresponds to decreasing $\mathrm{P}-\mathrm{T}$ conditions from 7 to $8 \mathrm{kbar} / 620^{\circ} \mathrm{C}$ to $\sim 4 \mathrm{kbar} / 500^{\circ} \mathrm{C}$ in the subhorizontal to moderately dipping S3 fabric. In the Southern Domain, chlorite develops in the axial plane of F3 microfolds and is not in equilibrium with garnet. The resulting $\mathrm{P}-\mathrm{T}$ path during D3 is therefore a prolonged retrograde evolution (Figure 11c) toward temperatures lower than $550^{\circ} \mathrm{C}$ [Śtipská et al., 2012]. In the Western Domain, chlorite is abundant in garnet pressure shadows related to the D3 deformation indicating that the metamorphic peak was followed by a decrease in both pressure and temperature during the formation of the S3 foliation (Figure 11c).

\subsection{Metamorphic Gradients During Polyphase Deformation}

[39] A large number of metapelite samples has been investigated in order to produce a map of metamorphic isograds, while field observations and lithological maps [Don et al., 2003; Żelaźniewicz et al., 2006] were used to assess the extent of anatexis in orthogneiss. In addition, the mineral parageneses in metasedimentary rocks were combined with the hitherto reported $\mathrm{P}-\mathrm{T}-\mathrm{d}$ data to qualitatively constrain the $\mathrm{P}-\mathrm{T}$ regime of each macroscopic fabric (Figures 10 and 11).

[40] Few observations in metapelites indicate that the D1 deformation is generally associated with prograde metamorphism with only small $\mathrm{P}-\mathrm{T}$ differences between the different parts of the Stronie formation (Figures 11a and 11c). However, the underlying orthogneisses show a marked metamorphic contrast (Figure 11a). Whereas partial melting occurs around the granulite belt, along the eastern boundary of the OSD and to the west of the eclogite belt, orthogneiss located to the east of the eclogite shows a dominant mylonitic texture (Figure $8 \mathrm{f}$ ).

[41] In most of the metasedimentary synforms, the D2 deformation can be associated with a continuous progression of metamorphism toward contrasted peak conditions (Figures $11 \mathrm{~b}$ and 11c). While the mineral parageneses from the belts located next to high-grade bodies document a prograde evolution reaching kyanite grade, metapelites occurring farther preserve only lower grade or even retrograde assemblages. This is reflected by flat HT-LP prograde gradients far from the granulite belt (Figure 11, paths II and III), but steeper MT-MP gradients observed close to it (Figure 11, 
paths IV-VI). The resulting metamorphic isograds define a concentric pattern showing decreasing pressure and temperature away from the eastern migmatite-granulite antiform (Figure 11b). In the Western Domain, a similar decrease in metamorphic conditions toward the west is highlighted by the isograd pattern that has been partly drawn after Opletal et al. [1980]. During the D2 stage, all orthogneiss bodies were deformed under the same thermal regime that prevailed during the D1 event, i.e., hot migmatitic orthogneiss dominates to the east of the OSD (Figure 10g), whereas lower temperature domains (Figure 10f) with limited zones of anatexis are present around the eclogite belt and in the Western Domain (Figure 11b).

[42] In the Stronie formation, the S3 foliation always develops under retrograde conditions, but is associated with a variable thermal regime. Around the migmatite-granulite antiform, sillimanite and andalusite occurrences (Figure 10b) suggest the persistence of high temperature conditions compared to the rest of the OSD where D3 develops in the chlorite stability field (Figure 11c). In the same way, deformation in the orthogneiss around the granulite belt is mostly associated with partial melting while in the Southern Domain the weak D3 deformation appears to be nearly at solid state. In the Western Domain, limited syn-D3 partial melting is also observed.

\section{Deep Structure of the OSD}

\subsection{Gravity Map}

[43] The objective of a geophysical investigation was to estimate the spatial distribution of the major tectonic contacts and the volumes of felsic gneiss-type lithologies at depth. In order to image the deep structure of the West and Central Sudetes, a set of 2D gravity models was computed (see Text A10). The Bouguer anomalies range from $-50 \mathrm{mGal}$ to $5 \mathrm{mGal}$ in the whole Sudetes, and four main NE-SW trending anomalies can be identified from NW to SE (Figure 12a). To the NW, a gravity low associated with the Lusatian massif and the Karkonosze granite is followed by a gravity high corresponding to the Rudawy Janowickie and Leszczyniec units and the unknown basement of the IntraSudetic basin (Teplá-Barrandian domain [Guy et al., 2010]). A large gravity low occurring in the center corresponds to the OSD, whereas the large gravity high to the SE is correlated with high density rocks of the Brunia basement and the eastern part of the Silesian domain [Dudek, 1980].

\subsection{Gravity Modeling}

[44] We present here two profiles extracted from a Bouguer gravity grid using the IGMAS (Interactive Gravity and Magnetic Application System) software for the 2D gravity modeling [Götze, 1984; Götze and Lahmeyer, 1988; Schmidt and Götze, 1998, 1999]. The density assignments for the modeling presented in Figure 12 take into account measurements from previous works of Ondra and Hanák [1984], Hrouda and Chlupáčová [1993], and Švancara and Chlupáčová [1994] (see Text S1).

[45] The NW gravity low is associated with a large $\sim 5 \mathrm{~km}$ thick body of low density $\left(2.65 \mathrm{~g} / \mathrm{cm}^{3}\right)$ material which reflects mainly the Karkonosze granite but probably also Neoproterozic and Ordovician orthogneiss. The adjacent SE gravity high is composed of two sub-maxima. The more important one is located to the NW and is modeled as two attached high density bodies $\left(2.9 \mathrm{~g} / \mathrm{cm}^{3}\right)$ gently dipping to the SW. Starting from the NW the first dense body corresponds to an accretionary prism containing high to medium density amphibolite and HP rocks formed during oceanic subduction of the Saxothuringian basin beneath the TepláBarrandian upper plate. The second dense body, located farther to the SE, represents Ordovician basalt and gabbro forming the Teplá-Barrandian lower crust. This latter structure plunges at a moderate angle below a 2 to $8 \mathrm{~km}$ thick Teplá-Barrandian upper crust represented by the Nové Město unit with a mean density of $2.75 \mathrm{~g} / \mathrm{cm}^{3}$. The high amount of metasedimentary rocks in the Nové Město unit is responsible for a relative gravity low separating two gravity highs. A gravity peak corresponds to the presence of the Nowa Ruda ophiolite body and Precambrian partly mafic crust of the Kłodzko massif. Still farther to the SE, a gravity low is mainly due to the presence of thick masses of orthogneiss of the OSD with a density of $\sim 2.67 \mathrm{~g} / \mathrm{cm}^{3}$. The felsic low density material is modeled beneath the Teplá-Barrandian rocks at mid-crustal depth linking large gravity lows that are centered at the OSD and the Karkonosze massif.

[46] Underneath the thickest felsic crustal bulge, at a depth of 20 to $30 \mathrm{~km}$, we expect the presence of high density eclogite and mafic granulite similar to those exhumed in the core of the OSD. High density rocks at the bottom of a thick felsic root are required to counterbalance the overlying low density material. In addition, high frequency anomalies superposed on the main gravity low are modeled as shallow synclines of the Stronie metasedimentary rocks. A local gravity high at the eastern border of the OSD roughly coincides with the trend of gabbro and amphibolite of the Staré Město unit. The slight shift of the anomaly toward the west is explained by the general westward dip of this belt to several kilometres depth. The southernmost negative gravity anomaly corresponds to a $8-10 \mathrm{~km}$ thick granite body (Žulová pluton) underplated by the orthogneissic nappes of the Moravo-Silesian domain [Rychtár and Rybák, 1987]. Finally, the large gravity high to the east is modeled as the Brunia microcontinent using intermediate densities of the middle crust and high densities of the lower crust according to the tectonic model of Finger et al. [2000]. The sharp gradient between the OSD and the Brunia basement is modeled as a steeply dipping tectonic boundary which is typical for the contact between the Brunia microcontinent and the western orogenic root in this region.

\section{Discussion}

\subsection{Constraints on the Pre-Collisional Domains}

[47] The combination of geochronological and geophysical data provides constraints on the probable initial stage of the orogenic evolution. In the OSD core, the Śnieżnik and Gierałtów orthogneiss varieties yield protolith ages of 510 $490 \mathrm{Ma}$ and are thought to reflect an important CambroOrdovician magmatic event [e.g., Turniak et al., 2000]. They bear a strong geochemical resemblance to the orthogneissic rocks of the Karkonosze massif that were similarly derived from porphyritic granite emplaced during voluminous Cambro-Ordovician calc-alkaline magmatism [Kröner et al., 2001]. Furthermore, new detrital zircon ages suggest 

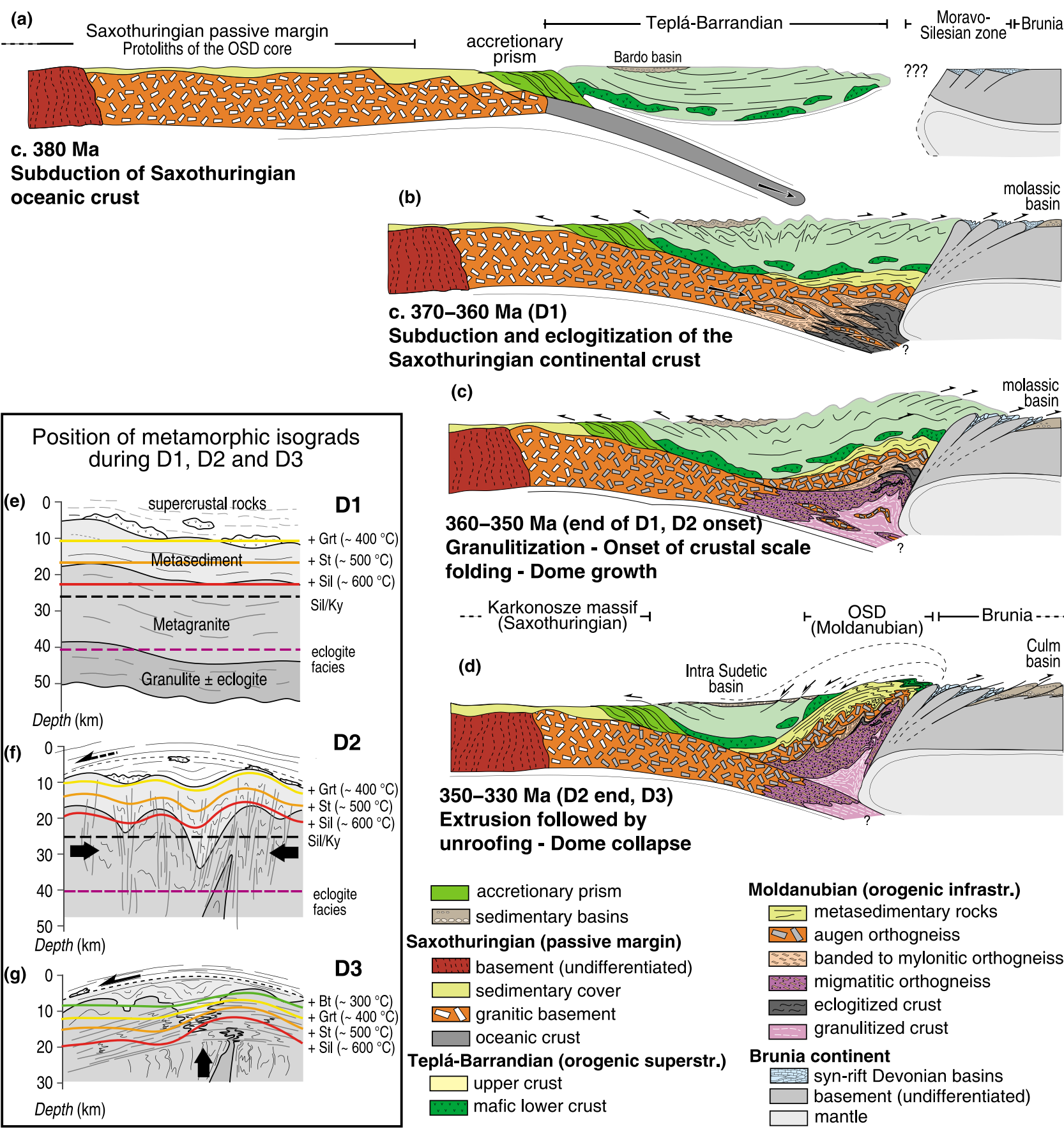

(c)

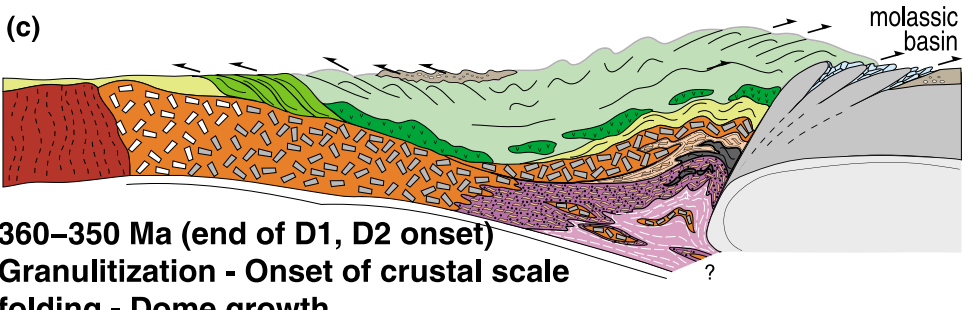
folding - Dome growth

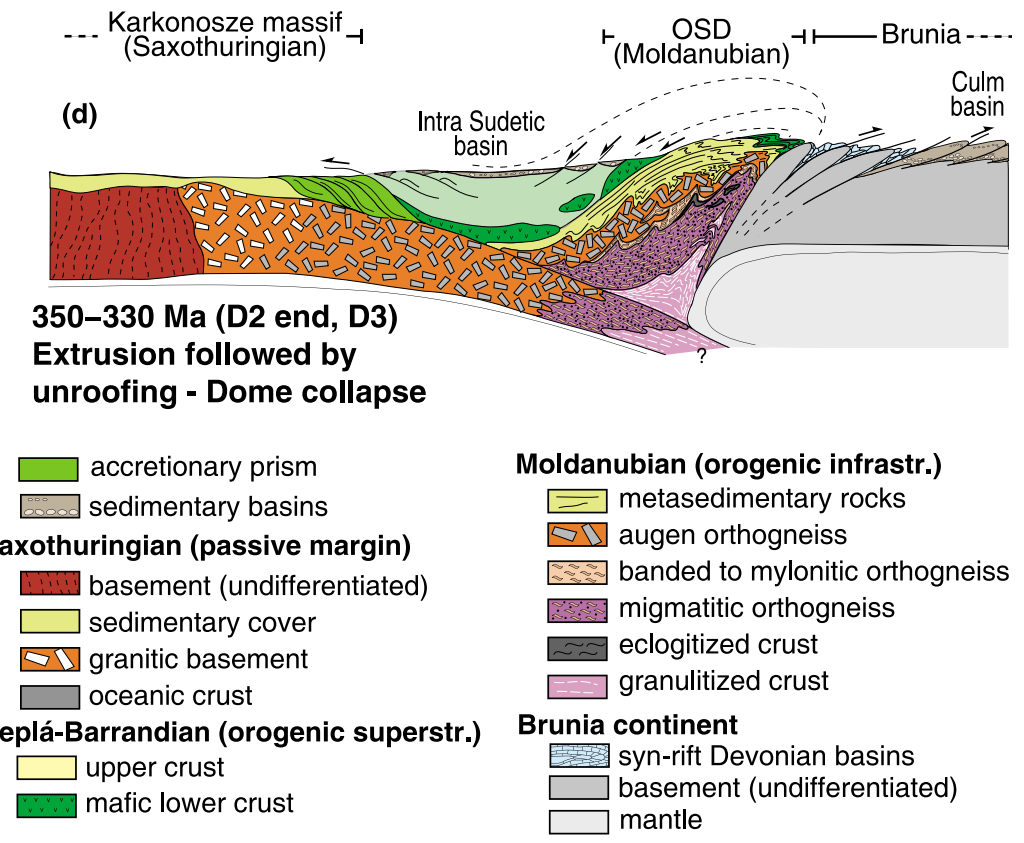

Figure 13. Idealized model for the evolution of the Orlica-Śnieżnik dome as a part of the Sudetes. See text for discussion.

that the sedimentary precursors of the Młynowiec and Stronie formations were deposited from the Neoproterozoic to the Lower Ordovician [Mazur et al., 2012]. Widespread Cambro-Ordovician felsic magmatism and abundant Early Palaeozoic sedimentation are commonly documented in the Variscan Belt of Europe, and especially in the Saxothuringian zone [e.g., Falk et al., 1995; Kemnitz et al., 2002] for which the West Sudetes are thought to be an eastward prolongation [Franke and Żelaźniewicz, 2000]. The Moldanubian OSD core and the Saxothuringian Karkonosze massif could therefore correspond to lateral equivalents, though they have been ascribed to different Variscan lithotectonic zones [e.g., Matte et al., 1990].

[48] In contrast, the rocks cropping out between the Karkonosze massif and the OSD core show different characteristics. The Nové Město and Zábřeh units, belonging to the OSD mantle, can be paralled to the Neoproterozoic volcano-sedimentary succession of the Teplá-Barrandian zone [Chaloupský et al., 1995; Mazur et al., 2005]. This discordance between the Karkonosze massif, the OSD mantle units, and the OSD core region coincides with the gravity anomaly distribution in the Sudetes. The orthogneisses that 
are mostly of Cambro-Ordovician age (the Karkonosze massif and OSD core) correspond to large gravity lows, whereas the Neoproterozoic OSD mantle units are associated with a prominent zone of high gravity anomaly in between (Figure 12a). Gravity modeling is compatible with the interpretation that the whole core of the OSD is formed by metagranitic orthogneiss and even suggests that it possibly extends toward the NW at depth into the Karkonosze massif (Figures 12b and 12c). Accordingly, the higher grade OSD core can be seen as a deformed and metamorphosed allochtonous part of the Saxothuringian zone with respect to the surrounding autochtonous OSD mantle represented by the Nové Město and Zábřeh units to the west and the relicts of the Cambro-Ordovician Staré Město rift to the east (Figure 13a).

\subsection{Significance of D1: Crustal Influx Into the Continental Wedge}

[49] The D1 deformation affected a pre-collisional crustal structure that was represented by sediments of the Stronie and Młynowiec formations intruded by voluminous granitic bodies. This resulted in the formation of a subhorizontal S1 foliation in all the different lithologies forming the presentday OSD core. In the metasedimentary rocks, this fabric is associated with prograde metamorphism along a MP-MT gradient reaching relatively homogeneous garnet- to staurolitegrade conditions (Figures 11 and 13e). In contrast, the eclogite and mylonitic orthogneiss from the Southern Domain document a prograde evolution along a HP-LT gradient reaching eclogite-facies conditions [Chopin et al., 2012; Štípská et al., 2012], while the intermediate and mafic granulites from the Northern Domain equilibrated in the HP granulite field during D1 [Štípská et al., 2004].

[50] The P-T conditions in HP rocks are typical of a subduction setting involving both mafic and felsic continental material. Moreover, the tectono-metamorphic evolution suggests that this burial event is associated with the development of a subhorizontal S1 fabric (Figures 13a-13c). This allows interpretion of the D1 deformation as the result of horizontal influx of crustal material into a continental wedge [Plesch and Oncken, 1999] (Figures 13a-13c). The subducted material corresponds to Neoproterozoic sediments, Late Cambrian granite intrusions and basic dykes covered by Early Palaeozoic deposits and is thought to represent a Cambro-Ordovician passive margin sequence of Saxothuringian affinity [see also Mazur et al., 2012]. Therefore, the OSD core can be considered as an allochtonous lower plate that was subducted below the TepláBarrandian upper plate represented by the present-day OSD mantle units (Figures 13a and 13b).

[51] During the D1 event, prograde metamorphism in metasedimentary and HP rocks followed different $\mathrm{P}-\mathrm{T}$ paths (Figure 3 ). This is ultimately reflected by a major pressure break of $\sim 10-12 \mathrm{kbar}$ between metapelites and HP rocks that reached $\sim 7 \mathrm{kbar} / 600^{\circ} \mathrm{C}$ and $\sim 20 \mathrm{kbar} / 700^{\circ} \mathrm{C}$, respectively [Štipská et al., 2012]. Consequently, the granulite, eclogite and mylonitic orthogneiss can be defined as orogenic lower crust [Schulmann et al., 2005, 2008], while the metasedimentary rocks can be regarded as orogenic middle crust with the augen orthogneiss as a transitional layer separating both crustal levels (Figure 13e). It highlights the fact that neither the Stronie-Młynowiec metasedimentary rocks nor the augen orthogneiss experienced widespread HP metamorphic conditions. The contrasting metamorphic gradients between the MP-MT Stronie metasedimentary rocks and HP-LT eclogite and orthogneiss are explained by the continuous underplating of felsic material; this kept the metasedimentary units at a relatively moderate crustal level while the granulitized and eclogitized units underwent deep subduction and subsequent subcretion at the bottom of the continental wedge [e.g., Johnston and Canil, 2007].

[52] In the central part of the dome, the D1 linear fabrics and associated kinematic criteria suggest a top to the $\mathrm{N}$ shearing parallel to the boundary of the Brunia microcontinent (Figure 7). This general N-S stretching in the OSD core led Pressler et al. [2007] and Chopin et al. [2012] to propose a model of constriction perpendicular to the main tectonic transport. Such an orthogonal flow of material in crustal wedges is reported from several orogens and by various authors [e.g., Indares et al., 2000; Duclaux et al., 2007; Jeřábek et al., 2008; Kuiper et al., 2011] who suggest that orogen-parallel stretching, which is perpendicular to the main direction of thrusting in a wedge, may occur within rheologically weaker units that are bounded by strong thrust sheets. However, this model is applicable only if the synconvergent orogen-parallel stretching is compensated by extrusion of the lateral foreland [Seyferth and Henk, 2004].

\subsection{Significance of D2: Indentation of the Wedge}

[53] In the eastern and central parts of the OSD, the D2 deformation is characterized by the development of $\mathrm{N}-\mathrm{S}$ to $\mathrm{NE}-\mathrm{SW}$ trending antiformal structures cored by the orogenic lower crust which alternate with narrow synforms composed of the metasedimentary middle crust (Figure 14). The main feature associated with the D2 event is the subvertical S2 axial planar cleavage which is developed in the HP belts and surrounding gneissic anticlines as well as in the adjacent synclines of the Southern and Northern Domains (Figures 6 and 14). The metamorphic character of this S2 fabric in mid- and lower crustal lithologies led Śtípská et al. [2004] and Skrzypek et al. [2011a] to propose that the D2 deformation results from a kilometre-scale folding of the orogenic crust. However, the intensity of the S2 fabric gradually decreases from SE to NW in the Northern Domain (Figure 9a), and from $\mathrm{E}$ to $\mathrm{W}$ in the Southern Domain (Figure 9b). This vanishing deformation gradient probably reflects a decrease in fold amplitude away from the core of the eastern migmatite-granulite anticline. In addition, Štipská et al. [2012] interpreted this folding as parasitic with respect to a larger crustal-scale folding of the whole OSD. In this view, the successive gneissic anticlines can be considered as subdomes [e.g., Kruckenberg et al., 2011] within the wider Orlica-Śnieżnik dome.

[54] During the development of the S2 foliation, metasedimentary rocks reached contrasting peak $\mathrm{P}-\mathrm{T}$ conditions. The spatial distribution of metamorphic isograds is tightly linked to the heterogenous D2 structural pattern (Figure 11b). Indeed, the metapelites reach kyanite grade next to the large migmatite-granulite anticline in the eastern part of the OSD, whereas they show progressively decreasing metamorphic conditions, from a sillimanite to garnet grade toward the west. A similar isograd pattern is repeated in the Western Orlica Domain, suggesting that a high-grade subdome could also be presently hidden beneath the Upper Cretaceous sediments of 


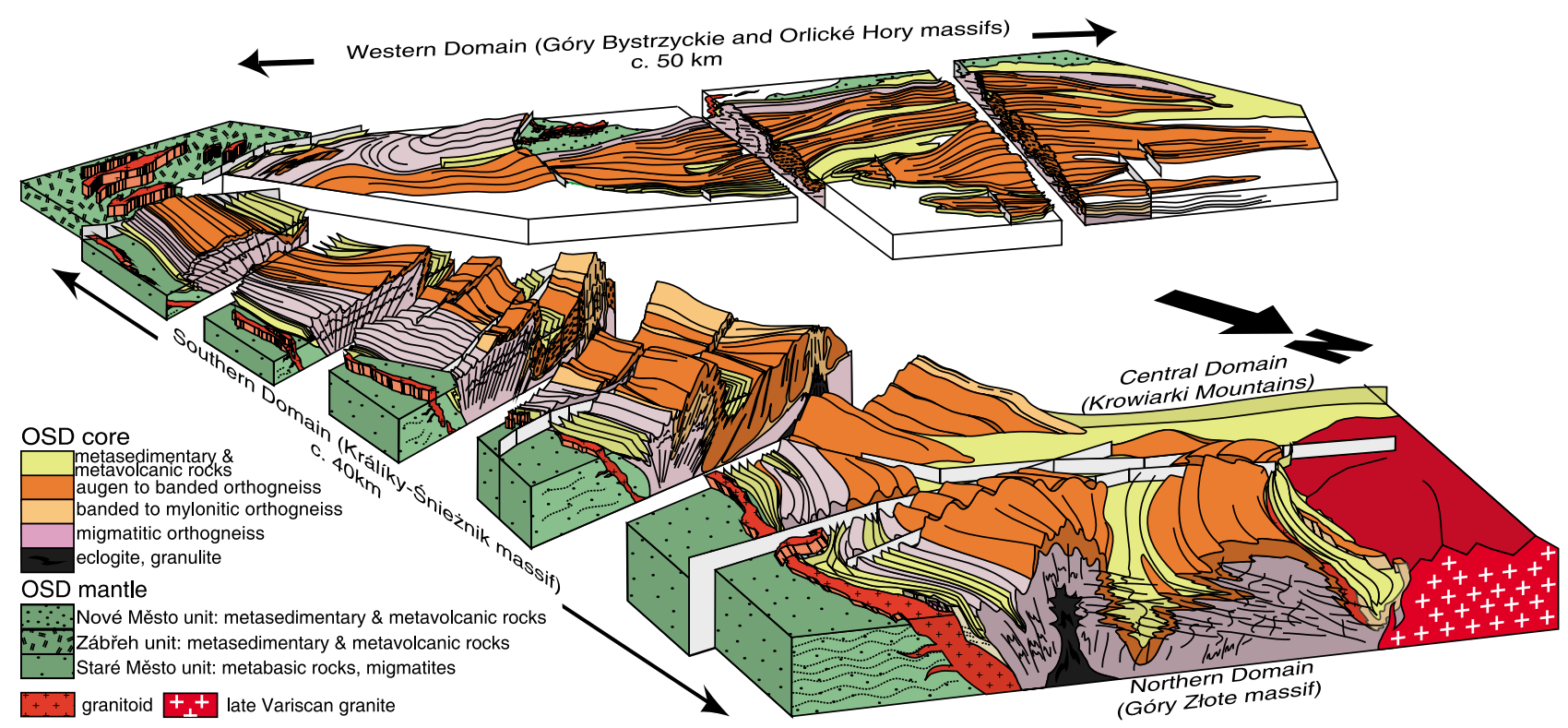

Figure 14. A 3D block diagram of the Orlica-Śnieżnik dome showing major structural features. The subhorizontal planar structures within the Staré Město unit represent the compositional banding of layered amphibolite developed during Middle-Late Cambrian extension [Štípská et al., 2001].

the Nysa Graben. Variable P-T paths can be the result of varying initial positions with respect to the axis of a rising diapiric dome [e.g., Warren and Ellis, 1996]. However, this would imply the metamorphic assemblages to be developed in different fabrics between rocks located in the apical part of the dome (horizontal foliation) or in marginal synclines (vertical foliation) [Burg et al., 2004]. We therefore suggest that the D2 metamorphic isograd pattern more likely reflects increasing burial in cusp-like synclines together with folding of the isotherms [e.g., Chamberlain, 1986] toward the rising gneiss subdomes (Figure 13f). As mentioned above, it is coeval with the large-scale doming of the OSD core (Figures 13c and 13d). Within the OSD, the growing gneiss subdomes are then likely to supply heat to metasedimentary rocks that are pinched in the neighboring synclines, whereas those located farther away would record a weaker prograde metamorphism (Figure 11, paths I-II) or even retrogression during D2 (Figure 11, paths III and IV).

[55] The variable intensity of the D2 deformation and associated metamorphism can be interpreted in terms of a progressive indentation of the OSD from the east by a continental promontory (Figure 13c). The resulting strain distribution in front of an oblique indenter was successfully modeled by Ježek et al. [2002] and Lexa et al. [2003], though this model generates a finite strain pattern without folding. Alternatively, Bott and Dean [1973] and Blay et al. [1977] proposed a model of progressive deformation and stress transfer across a visco-elastic plate leading to progressive fold propagation away from the indenter as the early folds lock up and harden during progressive shortening. A subsequent mechanism of post-buckle flattening is responsible for the continuous passive amplification of folds close to the indenting plate and produces the above mentioned cleavage front (Figure 9). Along the margins of the OSD core, this horizontal shortening is chiefly accommodated by transcurrent movements like dextral transtension and transpression which are documented in the Nové Město and the Staré Město units, respectively [Mazur et al., 2005; Parry et al., 1997].

\subsection{Significance of D3: Ductile Thinning}

[56] The latest D3 deformation is expressed by a subhorizontal S3 foliation that affects the previous fabrics mostly in the western and northeastern parts of the OSD (Figures 6 and 14). In all the metasedimentary belts, this shallow-dipping foliation is associated with decreasing $\mathrm{P}-\mathrm{T}$ conditions (Figures 11c and 14). The retrograde metamorphic evolution is shared by the orthogneissic anticlines that still show partial melting during D3 (Figure 11c).

[57] In the Western domain, the pervasive S3 foliation consistently dips to the $\mathrm{W}$ or SW (Figure 6). It is concordant with the discrete low-temperature to semi-brittle normal dipslip shear zones inclined toward the W [Mazur et al., 2005], i.e., toward the adjacent IntraSudetic basin, which are developed along the margin of the OSD core (Figure 9c). This overall structural pattern together with the several kilometres thick sedimentary infill of the IntraSudetic Basin points to the activity of a major crustal detachment. However, Mazur et al. [2005] have proposed that the juxtaposition of the Nové Město unit with the core of the OSD took place earlier under a right-lateral transtensional regime parallel to their $\mathrm{N}-\mathrm{S}$ boundary. It is therefore possible that the OSD core and mantle regions were already juxtaposed at the end of the D2 deformation. In contrast, the eastern Staré Město unit is affected by greenschist-facies dextral transpression and thrusting during D3 deformation. This highlights the difference between the eastern compressive and the southwestern and northern collapsing parts of the OSD mantle [Lehmann, 2009].

[58] The second area affected by the D3 deformation is located in the Northern Domain (Figure 14). It is represented by a moderately NW dipping zone of subhorizontal 
foliations that extends from the SE migmatite-granulite anticline to the northernmost syncline which is almost unaffected by D3 (Figure 9a and 14). In all the metasedimentary synclines surrounding the migmatite-granulite anticline, the $\mathrm{S} 3$ foliation is associated with relatively hot conditions reflected by HT-MP to HT-LP mineral assemblages (Figure 11c). In the metapelites located to the NW of the granulite belt, Skrzypek et al. [2011a] have shown that the D3 is characterized by an isobaric decompression from 7 to $3 \mathrm{kbar}$ followed by a $\mathrm{P}-\mathrm{T}$ decrease below $\sim 3 \mathrm{kbar}$ and $500^{\circ} \mathrm{C}$ during the joint exhumation with the neighboring $\mathrm{HP}$ rocks. Because garnet porphyroblasts in mica schist additionally show limited rotation during D3 [Skrzypek et al., 2011b], exhumation was ascribed to a pure shear-dominated ductile thinning mechanism similar to what has been observed in parts of the French Massif Central [Aerden, 1998].

[59] In summary, the D3 deformation leads to a heterogeneous flattening of the vertical S2 anisotropy across the OSD. In the classical orogenic wedge terminology, exhumation during the development of subhorizontal fabrics is related to ductile thinning of a progressively growing crustal wedge [Feehan and Brandon, 1999; Ring and Brandon, 1999]. However, ductile thinning followed by detachment can also be a typical feature of a gravity-driven rise of a crustal dome [Burg et al., 2004; Rey et al., 2009]. In conclusion, the D3 event is interpreted as a coaxial ductile thinning affecting the hotter and deeper axial part of the dome (Northern Domain), and progressively evolving toward a greenschist-facies non-coaxial detachment in the rapidly cooled and exhumed peripheral parts of the dome (Western and Southern Domains) (Figure 13d). It is additionally proposed that the present-day distribution of gravity anomalies (Figure 12a) was acquired during this crustal-scale exchange between the dense orogenic superstructure and the lighter orogenic infrastructure.

\subsection{Significance of Age Distribution}

[60] There are two possibilities to explain the spatial distribution of cooling ages reported in Figure 4. Either the earlier cooled areas have been exhumed before the younger ones or the differences result from the thermal effect of the migmatite-granulite anticline. Because prograde sillimanitebearing syn-D2 assemblages are found in the northern and central parts of the earlier cooled domain (A) (compare Figures 4 and $11 \mathrm{~b}$ ), the former hypothesis can be excluded. It means that these areas were still located close to the $600^{\circ} \mathrm{C}$ isotherm during D2 (Figure 13g). Exhumation of the whole system must have therefore started during the growth of the migmatite-granulite anticline to the east at around 350 $340 \mathrm{Ma}$, i.e., when the central parts of the dome crossed the $350-400^{\circ} \mathrm{C}$ isotherm. This model corroborates the cooling ages of the OSD mantle units which indicate that the orogenic superstructure crossed the $500^{\circ} \mathrm{C}$ and $320^{\circ} \mathrm{C}$ isotherms at around 350-340 Ma.

[61] To the east of the OSD core, the migmatitic-granulite anticline dome is characterized by younger cooling ages of 340-330 Ma (Figure 4). It coincides with the D3 isograd pattern reflecting the persistence of a thermal anomaly around the exhumed granulite belt (Figure 11c). It is therefore suggested that this subdome advected heat closer to the surface and cooled more slowly than the domains located to the west (Figure 13g). In the Western Domain, similar ages of 340-330 Ma are obtained in the D3 related fabrics (Figure 4). It is probably due to a strong syn-D3 recrystallization of muscovite and hornblende which may be responsible for the entire resetting of the Ar isotopic system. Soon after D3, the deep-seated rocks reached the surface so that a large portion of the apical part of dome started to be eroded. Indeed, erosion of high-grade basement, and especially the OSD core have been proposed [Teisseyre, 1968, 1975; Dziedzic and Teisseyre, 1990; Awdankiewicz et al., 2003] to explain the abundant influx of sediments into the neighboring IntraSudetic basin.

\section{Conclusion: A Geodynamic Model for the Growth of the OSD}

[62] We propose a schematic evolutionary model for the formation of the continental wedge and the origin of the OSD. Continental subduction is responsible for eclogitefacies metamorphism along a HP-LT gradient in various rock types appearing today in the center of the OSD core (Figure 13b). Continuous underthrusting of continental crust leads to progressive underplating of the early HP rock assemblage by felsic and intermediate rocks which were partly transformed into HP granulite, HP orthogneiss and migmatite. These rocks presently form the eastern part of the OSD core (Figure 13c). The subsequent folding due to a buttressing effect of the advancing Brunia promontory deformed the whole crustal wedge (Figure 13c), and the prolonged influx of felsic material led to the growth of crustal-scale folds which affected the whole orogenic infrastructure. At the same time, kilometre-scale folding within the infrastructure produced vertical exchanges of material and heat between the middle crust and exhumed lowercrustal subdomes (Figure 13f). The continuous subcretion of mostly felsic material culminated in ductile thinning laterally evolving to detachment and unroofing of the central part of the OSD while erosion was probably intensely active (Figure 13d). Although the tectono-metamorphic records in metasedimentary synforms account for a strong influence of lateral forces, the large amount of felsic material in the OSD core may suggest an additional contribution of gravitational forces [Gerya et al., 2004] between a dense superstructure and a lighter infrastructure during the evolution of the dome.

[63] Even if Middle to Late Devonian (i.e., eo-Variscan) deformation has been inferred in the Teplá-Barrandian crust [Kroner et al., 2007] and within the OSD [Anczkiewicz et al., 2007], the timing of the initiation of the continental subduction and the record of HP metamorphism are not well-established [Bröcker et al., 2009]. We assume that this early deformation event is related to the eastward Devonian subduction of a Late Cambrian to Ordovician oceanic domain [Oliver et al., 1993] and the obduction of an accretionary wedge over the eastern Neoproterozoic passive margin of the Saxothuringian zone (Figure 13a). The subduction progressed to continental underthrusting of the Saxothuringian continental passive margin which is mostly composed of Cambro-Ordovician granitoids. As a result, this continental portion was dragged underneath the autochtonous Teplá-Barrandian crust corresponding to Neoproterozoic sequences of the Zábřeh and Nové Město units 
(Figure 13b). In such a view, the Moldanubian zone would be merely defined as a recycled passive margin from the Saxothuringian zone.

[64] Acknowledgments. Financial support of the French National Grant Agency (06-1148784 to Karel Schulmann) is acknowledged. The grant MSM0021620855 of the Ministry of Education of the Czech Republic and internal research funds of CNRS UMR 7517 are acknowledged for salary and financial support of Ondrej Lexa. We thank Jaroslav Synek for drawing Figures 13 and 14 and Annie Bouzeghaia for helpful suggestions during drawing of the figures. Access to the bibliography was possible thanks to the outstanding collection held at the University of Strasbourg, and the careful work of the person in charge Betty Kieffer. We are grateful to Stanisław Mazur and Paweł Aleksandrowski for detailed constructive reviews. Onno Oncken is thanked for his editorial work.

\section{References}

Aerden, D. G. A. M. (1998), Tectonic evolution of the Montagne Noire and a possible orogenic model for syncollisional exhumation of deep rocks, Variscan belt, France, Tectonics, 17(1), 62-79, doi:10.1029/97TC02342.

Aleksandrowski, P., and S. Mazur (2002), Collage tectonics in the northeasternmost part of the Variscan Belt: The Sudetes, Bohemian Massif, in Palaeozoic Amalgation of Central Europe, edited by J. A. Winchester, T. C. Pharaoh, and J. Vernier, Geol. Soc. Spec. Publ., 201, 237-277, doi:10.1144/GSL.SP.2002.201.01.12.

Aleksandrowski, P., R. Kryza, S. Mazur, and J. Żaba (1997), Kinematic data on major Variscan strike-slip faults and shear zones in the Polish Sudetes, northeast Bohemian Massif, Geol. Mag., 134(5), 727-739, doi:10.1017/S0016756897007590.

Anczkiewicz, R., J. Szczepański, S. Mazur, C. Storey, Q. Crowley, I. M. Villa, M. E. Thirlwall, and T. E. Jeffries (2007), Lu-Hf geochronology and trace element distribution in garnet: Implications for uplift and exhumation of ultra-high pressure granulites in the Sudetes, SW Poland, Lithos, 95(3-4), 363-380, doi:10.1016/j.lithos.2006.09.001.

Awdankiewicz, M., L. Kurowski, K. Mastalerz, and P. Raczyński (2003), The Intra-Sudetic Basin-A record of sedimentary and volcanic processes in late-to post-Orogenic tectonic setting, Geolines, 16, 165-183.

Bakun-Czubarow, N. (1991), On the possibility of occurrence of quartz pseudomorph after coesite in the eclogite-granulite rock series of the Złote Mountains in the Sudetes (SW Poland), Arch. Mineral., 47(1), 5-16.

Bakun-Czubarow, N. (1992), Quartz pseudomorphs after coesite and quartz exsolutions in eclogitic omphacites of the Złote Mountains in the Sudetes (SW Poland), Arch. Mineral., 48(1-2), 3-25.

Bakun-Czubarow, N. (1998), Ilmenite-bearing eclogites of the West Sudetestheir geochemistry and mineral chemistry, Arch. Mineral., 51(1-2), $29-110$

Baratoux, L., K. Schulmann, S. Ulrich, and O. Lexa (2005), Contrasting microstructures and deformation mechanisms in metagabbro mylonites contemporaneously deformed under different temperatures (c. $650^{\circ} \mathrm{C}$ and c. $750^{\circ} \mathrm{C}$ ), in Deformation Mechanisms, Rheology and Tectonics: From Minerals to Lithosphere, edited by D. Gapais, J. P. Brun, and P. R. Cobbold, Geol. Soc. Spec. Publ., 243, 97-125.

Beaumont, C., M. H. Nguyen, R. A. Jamieson, and S. Ellis (2006), Crustal flow modes in large hot orogens, in Channel Flow, Ductile Extrusion and Exhumation in Continental Collision Zones, edited by R. D. Law, M. P. Searle, and L. Godin, Geol. Soc. Spec. Publ., 268, 91-145.

Białek, D., and T. Werner (2004), Geochemistry and Geochronology of the Javornik Granodiorite and its Geodynamic Significance in the Eastern Variscan Belt, Geolines, 17, 22-23.

Blay, P., J. W. Cosgrove, and J. M. Summers (1977), An experimental investigation of the development of structures in multilayers under the influence of gravity, J. Geol. Soc., 133(4), 329-342, doi:10.1144/ gsigs.133.4.0329.

Borkowska, M., P. Choukroune, J. Hameurt, and F. Martineau (1990), A geochemical investigation of the age, significance and structural evolution of the Caledonian-Variscan granite-gneisses of the Snieżnik metamorphic area (Central Sudetes, Poland), Geol. Sudetica, 15, 1-27.

Bott, M. H. P., and D. S. Dean (1973), Stress diffusion from plate boundaries, Nature, 243(5406), 339-341, doi:10.1038/243339a0.

Bröcker, M., and R. Klemd (1996), Ultrahigh-pressure metamorphism in the Śnieżnik Mountains (Sudetes, Poland): P-T constraints and geological implications, J. Geol., 104(4), 417-433, doi:10.1086/629837.

Bröcker, M., R. Klemd, M. Cosca, W. Brock, A. N. Larionov, and N. Rodionov (2009), The timing of eclogite facies metamorphism and migmatization in the Orlica-Snieżnik complex, Bohemian Massif: Constraints from a multimethod geochronological study, J. Metamorph. Geol., 27(5), 385-403, doi:10.1111/j.1525-1314.2009.00823.x.
Bröcker, M., R. Klemd, E. Kooijman, J. Berndt, and A. Larionov (2010), Zircon geochronology and trace element characteristics of eclogites and granulites from the Orlica-Snieznik complex, Bohemian Massif, Geol. Mag., 147(3), 339-362, doi:10.1017/S0016756809990665.

Brown, M. (2007), Metamorphic conditions in orogenic belts: A record of secular change, Int. Geol. Rev., 49(3), 193-234, doi:10.2747/00206814.49.3.193.

Brun, J. P. (1983), L'origine des domes gneissiques: Modeles et tests, Bull. Soc. Geol. Fr., 25(2), 219-228.

Burg, J. P., B. J. P. Kaus, and Y. Y. Podladchikov (2004), Dome structures in collision orogens: Mechanical investigation of the gravity/compression interplay, in Gneiss Domes in Orogeny, edited by D. L. Whitney, C. Teyssier, and C. S. Siddoway, Spec. Pap. Geol. Soc. Am., 380, pp. 47-66, doi:10.1130/0-8137-2380-9.47.

Buriánek, D., K. Verner, P. Hanžl, and H. Krumlová (2009), Ordovician metagranites and migmatites of the Svratka and Orlice-Sněžník units, northeastern Bohemian Massif, J. Geosci., 54(2), 181-200, doi:10.3190/ jgeosci.049.

Chaloupský, J., I. Chlupáč, J. Mašek, J. Waldhausrová, and J. Cháb (1995), Teplá-Barrandian Zone (Bohemicum)-Stratigraphy, in Pre-Permian Geology of Central and Eastern Europe, edited by R. D. Dallmeyer, W. Franke, and K. Weber, pp. 379-391, Springer, Berlin.

Chamberlain, C. P. (1986), Evidence for the repeated folding of isotherms during regional metamorphism, J. Petrol., 27(1), 63-89, doi:10.1093/ petrology/27.1.63

Chopin, F., K. Schulmann, P. Štípská, J. E. Martelat, P. Pitra, O. Lexa, and B. Petri (2012), Microstructural and metamorphic evolution of a high pressure granitic orthogneiss during continental subduction (OrlicaŚnieżnik dome, Bohemian Massif), J. Metamorph. Geol., doi:10.1111/ j.1525-1314.2011.00970.x, in press.

Cymerman, Z. (1997), Structure, kinematics and evolution of the OrlicaŚnieżnik Dome, Sudetes, Prace Panstw. Inst. Geol., 156, 1-120.

Dewey, J. F., and J. M. Bird (1970), Mountain Belts and the new global tectonics, J. Geophys. Res., 75, 2625-2647, doi:10.1029/JB075i014p02625.

Don, J. (1964), Góry Złote i Krowiarki jako elementy składowe metamorfiku Śnieżnika (The Złote and Krowiarki Mountains as structural elements of the Śnieżnik metamorphic massif), Geol. Sudetica, 1, 79-117.

Don, J. (1982), Tectonika łupków strefy siennej oraz korelacja rozwoju gnejsów z etapami deformacji metamorfiku Śnieżnika (The Sienna synform and the relationship of gneisses to the deformational stages distinguished in the Snieznik metamorphic massif (Sudetes)), Geol. Sudetica, $17,103-124$.

Don, J., M. Dumicz, I. Wojciechowska, and A. Żelaźniewicz (1990), Lithology and tectonics of the Orlica-Śnieżnik Dome, Sudetes - Recent state of knowledge, Neues Jahrb. Geol. Palaeontol. Abh., 179(2-3), 159-188. Don, J., J. Skácel, and R. Gotowała (2003), The boundary zone of the East and West Sudetes on the 1:50 000 scale geological map of the Velke Vrbno, Staré Město and Śnieżnik Metamorphic Units, Geol. Sudetica, $35(1), 25-59$.

Duclaux, G., P. Rey, S. Guillot, and R.-P. Menot (2007), Orogen-parallel flow during continental convergence: Numerical experiments and Archean field examples, Geology, 35(8), 715-718, doi:10.1130/G23540A.1.

Dudek, A. (1980), The crystalline basement block of the Outher Carpathians in Moravia - Brunovistulicum, Rozpr. Cesk. Akad. Ved, 90(8), $1-85$

Dumicz, M. (1964), Geology of the crystalline massif of the Bystrzyckie Mts, Geol. Sudetica, 1, 169-208.

Dumicz, M. (1979), Tectogenesis of the metamorphosed series of the Kłodzko district: A tentative explanation, Geol. Sudetica, 14, 29-44.

Dziedzic, K., and A. K. Teisseyre (1990), The Hercynian mollase and younger deposits in the Intra-Sudetic Basin, SW Poland, Neues Jahrb. Geol. Palaeontol. Abh., 197, 285-305.

Edel, J. B., K. Schulmann, and F. V. Holub (2003), Anticlockwise and clockwise rotations of the Eastern Variscides accommodated by dextral lithospheric wrenching: Palaeomagnetic and structural evidence, J. Geol. Soc., 160, 209-218, doi:10.1144/0016-764902-035.

Eskola, P. E. (1948), The problem of mantled gneiss domes, Q. J. Geol. Soc., 104, 461-476, doi:10.1144/GSL.JGS.1948.104.01-04.21.

Fajst, M. (1976), New discordance in the pre-Cambrian of the Bohemian massif [in Czech], Cas. Mineral. Geol., 21(3), 257-275.

Falk, F., W. Franke, and M. Kurze (1995), Saxothuringian Basin: Autochton and Nonmetamorphic Nappe Units - Stratigraphy, Structure, and Igneous Activity, in Pre-Permian Geology of Central and Western Europe, edited by D. Dallmeyer, W. Franke, and K. Weber, pp. 221-234, Springer, Berlin

Feehan, J. G., and M. T. Brandon (1999), Contribution of ductile flow to exhumation of low-temperature, high-pressure metamorphic rocks: San Juan-Cascade nappes, NW Washington State, J. Geophys. Res., 104, 10,883-10,902, doi:10.1029/1998JB900054. 
Finger, F., P. Hanžl, C. Pin, A. von Quadt, and H. P. Steyrer (2000), The Brunovistulian: Avalonian Precambrian sequence at the eastern end of the Central European Variscides?, in Orogenic Processes: Quantification and Modelling in the Variscan Belt, edited by W. Franke et al., Geol. Soc. Spec. Publ., 179, 103-112, doi:10.1144/GSL.SP.2000.179.01.08.

Fischer, G. (1936), Der Bau des Glatzer Schneegebirges, Jahrb. Preuss. Geol. Landesanst., 56, 712-732.

Franěk, J., K. Schulmann, O. Lexa, Č. Tomek, and J. B. Edel (2011), Model of syn-convergent extrusion of orogenic lower crust in the core of the Variscan belt: Implications for exhumation of HP rocks in large hot orogens, J. Metamorph. Geol., 29, 53-78, doi:10.1111/j.15251314.2010.00903.x

Franke, W., and A. Żelaźniewicz (2000), The eastern termination of the Variscides: Terrane correlation and kinematic evolution, in Orogenic Processes: Quantification and Modelling in the Variscan Belt, Special Publications, 179, edited by W. Franke et al., Geol. Soc. Spec. Publ., 179, 63-86, doi:10.1144/GSL.SP.2000.179.01.06.

Gapais, D., F. Cagnard, F. Gueydan, P. Barbey, and M. Ballèvre (2009), Mountain building and exhumation processes through time: Inferences from nature and models, Terra Nova, 21(3), 188-194, doi:10.1111/ j.1365-3121.2009.00873.x.

Gerya, T. V., L. L. Perchuk, W. V. Maresch, and A. P. Willner (2004), Inherent gravitational instability of hot continental crust: Implications for doming and diapirism in granulite facies terrains, in Gneiss Domes in Orogeny, edited by D. L. Whitney et al., Spec. Pap. Geol. Soc. Am., 380, 97-115, doi:10.1130/0-8137-2380-9.97.

Götze, H. J. (1984), Über den Einsatz interaktiver Computergraphik im Rahmen 3-dimensionaler Interpretationstechniken in Gravimetrie und Magnetik, Habilitation thesis, 121 pp, Tech. Univ. Clausthal, ClausthalZellerfeld, Germany.

Götze, H. J., and B. Lahmeyer (1988), Application of three-dimensional interactive modeling in gravity and magnetics, Geophysics, 53(8), 1096-1108, doi:10.1190/1.1442546.

Guy, A., J.-B. Edel, K. Schulmann, Č. Tomek, and O. Lexa (2010), A geophysical model of the Variscan orogenic root (Bohemian Massif): Implications for modern collisional orogens, Lithos, 124(1-2), 144-157, doi:10.1016/j.lithos.2010.08.008.

Haller, J. (1956), Probleme der Tiefentektonik. Bauformen im MigmatitStockwerk der Ostgrönländischen Kaledoniden, Geol. Rundsch., 45 159-167, doi:10.1007/BF01802002.

Hrouda, F., and M. Chlupáčová (1993), Geologický model západní části Českého masívu ve vazbě na ultrahluboký VRT (KTB-1) V SRN. Zpráva za dílčí úkol 04: Petrofyzikální výzkum v západních Čechách ve vazbě na ultrahluboký vrt (KTB-1) v SRN, report, MS Geofyzika, a.s., Brno.

Indares, A., G. Dunning, and R. Cox (2000), Tectono-thermal evolution of deep crust in a Mesoproterozoic continental collision setting: The Manicouagan example, Can. J. Earth Sci., 37(2-3), 325-340, doi:10.1139/ e99-069

Jastrzebski, M. (2009), A Variscan continental collision of the West Sudetes and the Brunovistulian terrane: A contribution from structural and metamorphic record of the Stronie Formation, the Orlica-Śnieżnik Dome, SW Poland, Int. J. Earth Sci., 98(8), 1901-1923, doi:10.1007/s00531008-0357-5

Jeřábek, P., W. S. Faryad, K. Schulmann, O. Lexa, and L. Tajčmanová (2008), Alpine burial and heterogeneous exhumation of Variscan crust in the West Carpathians: Insight from thermodynamic and argon diffusion modelling, J. Geol. Soc., 165(2), 479-498, doi:10.1144/001676492006-165.

Ježek, J., K. Schulmann, and A. B. Thompson (2002), Strain partitioning parametres in front of an obliquely convergent indenter, in Continental Collision and the Tectono-Sedimentary Evolution of Forelands, Stephan Mueller Spec. Publ. Ser., vol. 1., edited by G. Bertotti, K. Schulmann, and S. Cloethingh, pp. 93-104, Copernicus, Katlenburg-Lindau, Germany.

Johnston, S. T., and D. Canil (2007), Crustal architecture of SW Yukon, northern Cordillera: Implications for crustal growth in a convergent margin orogen, Tectonics, 26, TC1006, doi:10.1029/2006TC001950.

Kemnitz, H., R. L. Romer, and O. Oncken (2002), Gondwana breakup and the northern margin of the Saxothuringian belt (Variscides of Central Europe), Int. J. Earth Sci., 91, 246-259, doi:10.1007/s005310100209.

Klemd, R., and M. Bröcker (1999), Fluid influence on mineral reactions in ultrahigh-pressure granulites: A case study in the Śnieżnik Mts. (West Sudetes, Poland), Contrib. Mineral. Petrol., 136(4), 358-373, doi:10.1007/ s004100050544.

Klemd, R., M. Bröcker, and J. Schramm (1995), Characterization of amphibolite-facies fluids of Variscan eclogites from the Orlica-Snieznik Dome (Sudetes, SW Poland), Chem. Geol., 119(1-4), 101-113, doi:10.1016/0009-2541(94)00096-Q.
Koppers, A. A. P. (2002), ArArCALC-software for ${ }^{40} \mathrm{Ar} /{ }^{39} \mathrm{Ar}$ age calculations, Comput. Geosci., 28(5), 605-619, doi:10.1016/S0098 3004(01)00095-4

Koyi, H. A., A. G. Milnes, H. Schmeling, C. J. Talbot, C. Juhlin, and H. Zeyen (1999), Numerical models of ductile rebound of crustal roots beneath mountain belts, Geophys. J. Int., 139(2), 556-562, doi:10.1046/ j.1365-246x.1999.00978.x.

Kozłowska-Koch, M. (1973), Polimetamorfity strefy tektonicznej Złoty Stok-Skrzynka w Sudetach, Geol. Sudetica, 8, 121-155.

Kozłowski, K. (1961), Kompleks granulitowy Starego Gierałtowa w Górach Złlotych (The granulitic complex of Stary Gierałtow - East Sudetes), Arch. Mineral., 25, 5-123.

Kretz, R. (1983), Symbols for rock-forming minerals, Am. Mineral., 68(1-2), 277-279

Kröner, A., P. Štípská, K. Schulmann, and P. Jaeckel (2000), Chronological constraints on the pre-Variscan evolution of the northeastern margin of the Bohemian Massif, Czech Republic, in Orogenic Processes; Quantification and Modelling in the Variscan Belt, Special Publication, 179 , edited by W. Franke et al., Geol. Soc. Spec. Publ., 179, 175-197, doi:10.1144/GSL.SP.2000.179.01.12.

Kröner, A., P. Jaeckel, E. Hegner, and M. Opletal (2001), Single zircon ages and whole rock $\mathrm{Nd}$ isotopic systematics of early Palaeozoic granitoid gneisses from the Czech and Polish Sudetes (Jizerské hory, Krkonoše Mountains and Orlice-Sneznik Complex), Int. J. Earth Sci., 90(2), 304-324, doi:10.1007/s005310000139.

Kroner, U., et al. (2007), Variscan tectonics, in The Geology of Central Europe-Volume 1: Precambrian and Palaeozoic, edited by T. McCann, pp 599-664, Geol. Soc. of London, London.

Kruckenberg, S. C., O. Vanderhaeghe, E. C. Ferré, C. Teyssier, and D. L. Whitney (2011), Flow of partially molten crust and the internal dynamics of a migmatite dome, Naxos, Greece, Tectonics, 30, TC3001, doi:10.1029/ 2010TC002751.

Kryza, R., C. Pin, and D. Vielzeuf (1996), High-pressure granulites from the Sudetes (south-west Poland): Evidence of crustal subduction and collisional thickening in the Variscan Belt, J. Metamorph. Geol., 14, 531-546, doi:10.1046/j.1525-1314.1996.03710.x.

Kuiper, Y. D., S. Lin, and D. Jiang (2011), Deformation partitioning in transpressional shear zones with an along-strike stretch component: An example from the Superior Boundary Zone, Manitoba, Canada, J. Struct. Geol., 33(3), 192-202, doi:10.1016/j.jsg.2010.07.003.

Lange, U., M. Bröcker, K. Mezger, and J. Don (2002), Geochemistry and $\mathrm{Rb}-\mathrm{Sr}$ geochronology of a ductile shear zone in the Orlica-Śnieżnik dome (West Sudetes, Poland), Int. J. Earth Sci., 91(6), 1005-1016, doi:10.1007/s00531-002-0281-z.

Lange, U., M. Bröcker, R. Armstrong, E. Trapp, and K. Mezger (2005a), $\mathrm{Sm}-\mathrm{Nd}$ and $\mathrm{U}-\mathrm{Pb}$ dating of high-pressure granulites from the Złote and Rychleby Mts (Bohemian Massif, Poland and Czech Republic), J. Metamorph. Geol., 23(3), 133-145, doi:10.1111/j.1525-1314.2005.00566.x.

Lange, U., M. Bröcker, R. Armstrong, A. Żelaźniewicz, E. Trapp, and K. Mezger (2005b), The orthogneisses of the Orlica-Śnieżnik complex (West Sudetes, Poland): Geochemical characteristics, the importance of pre-Variscan migmatization and constraints on the cooling history, J. Geol. Soc., 162, 973-984, doi:10.1144/0016-764904-095.

Le Pichon, X., P. Henry, and B. Goffe (1997), Uplift of Tibet: From eclogites to granulites - Implications for the Andean Plateau and the Variscan belt, Tectonophysics, 273(1-2), 57-76, doi:10.1016/S0040-1951(96) 00288-0.

Lehmann, J. (2009), Mécanismes de déformation dans les systèmes d'accrétion paléozoïques, $\mathrm{PhD}$ thesis, 280 pp, Univ. de Strasbourg, Strasbourg, France.

Lexa, O., K. Schulmann, and J. Jezek (2003), Cretaceous collision and indentation in the West Carpathians: View based on structural analysis and numerical modeling, Tectonics, 22(6), 1066, doi:10.1029/2002TC001472.

Lexa, O., P. Štípská, K. Schulmann, L. Baratoux, and A. Kröner (2005), Contrasting textural record of two distinct metamorphic events of similar P-T conditions and different durations, J. Metamorph. Geol., 23(8), 649-666, doi:10.1111/j.1525-1314.2005.00601.x.

Lexa, O., K. Schulmann, V. Janoušek, P. Štípská, A. Guy, and M. Racek (2011), Heat sources and trigger mechanisms of exhumation of HP granulites in Variscan orogenic root, J. Metamorph. Geol., 29(1), 79-102, doi:10.1111/j.1525-1314.2010.00906.x.

Maluski, H., and F. Patočka (1997), Geochemistry and ${ }^{40} \mathrm{Ar}-{ }^{39} \mathrm{Ar}$ geochronology of the mafic metavolcanic rocks from the Rýchory Mountains complex (west Sudetes, Bohemian Massif): Palaeotectonic significance, Geol. Mag., 134(5), 703-716, doi:10.1017/S0016756897007498.

Maluski, H., P. Rajlich, and J. Souček (1995), Pre-Variscan, Variscan and early Alpine thermo-tectonic history of the northeastern Bohemian Massif: An ${ }^{40} \mathrm{Ar} /{ }^{39} \mathrm{Ar}$ study, Geol. Rundsch., 84, 345-358, doi:10.1007/ s005310050010. 
Marheine, D., V. Kachlík, H. Maluski, F. Patočka, and A. Zelaźniewicz (2002), The ${ }^{40} \mathrm{Ar} /{ }^{39} \mathrm{Ar}$ ages from the West Sudetes (NE Bohemian Massif): Constraints on the Variscan polyphase tectonothermal development, in Palaeozoic Amalgation of Central Europe, edited by J. A. Winchester, T. C. Pharaoh, and J. Verniers, Geol. Soc. Spec. Publ., 201, 133-155, doi:10.1144/GSL.SP.2002.201.01.07.

Matte, P., H. Maluski, P. Rajlich, and W. Franke (1990), Terrane boundaries in the Bohemian Massif: Result of large-scale Variscan shearing, Tectonophysics, 177(1-3), 151-170, doi:10.1016/0040-1951(90)90279-H

Mazur, S., and P. Aleksandrowski (2001), The Tepla(?)/Saxothuringian suture in the Karkonosze-Izera massif, western Sudetes, central European Variscides, Int. J. Earth Sci., 90(2), 341-360, doi:10.1007/s005310000146.

Mazur, S., and R. Kryza (1996), Superimposed compressional and extensional tectonics in the Karkonosze-Izera Block, NE Bohemian Massif in Basement Tectonics 11: Europe and Other Regions, edited by O. Oncken and C. Janssen, pp. 51-66, Kluwer Acad., Dordrecht.

Mazur, S., P. Aleksandrowski, and J. Szczepański (2005), The presumed Teplá-Barrandian/Moldanubian terrane boundary in the Orlica Mountains (Sudetes, Bohemian Massif): Structural and petrological characteristics, Lithos, 82(1-2), 85-112, doi:10.1016/j.lithos.2004.12.008.

Mazur, S., P. Aleksandrowski, R. Kryza, and T. Oberc-Dziedzic (2006), The Variscan Orogen in Poland, Geol. Q., 50(1), 89-118.

Mazur, S., A. Kröner, J. Szczepański, K. Turniak, P. Hanžl, R. Melichar, N. V. Rodionov, I. Paderin, and S. A. Sergeev (2010), Single zircon $\mathrm{U}-\mathrm{Pb}$ ages and geochemistry of granitoid gneisses from SW Poland Evidence for an Avalonian affinity of the Brunian microcontinent, Geol. Mag., 147(4), 508-526, doi:10.1017/S001675680999080X.

Mazur, S., J. Szczepański, K. Turniak, and N. McNaughton (2012), Location of the Rheic suture in the eastern Bohemian Massif: Evidence from detrital zircon data, Terra Nova, doi:10.1111/j.1365-3121.2011.01053.x, in press.

Murtezi, M. (2006), The acid metavolcanic rocks of the Orlica-Śnieżnik Dome (Sudetes): Their origin and tectono-metamorphic evolution, Geol. Sudetica, 38, 1-38

Oliver, G. J. H., F. Corfu, and T. E. Krogh (1993), U-Pb ages from SW Poland: Evidence for a Caledonian suture zone between Baltica and Gondwana, J. Geol. Soc., 150, 355-369, doi:10.1144/gsjgs.150.2.0355.

Ondra, P., and J. Hanák (1984), Hustoty hlavních typů hornin oblast moldanubika na území ČSSR (Densities of principal rock types of the Moldanubicum on Czechoslovak territory), Cas. Mineral. Geol., 29(1), $19-28$.

Opletal, M., K. Domečka, and S. Čech (1980), Geologie Orlických Hor, 202 pp, Ústředni Ústav Geol., Prague.

Parry, M., P. Štípská, K. Schulmann, F. Hrouda, J. Ježek, and A. Kröner (1997), Tonalite sill emplacement at an oblique plate boundary: Northeastern margin of the Bohemian Massif, Tectonophysics, 280(1-2), 61-81, doi:10.1016/S0040-1951(97)00146-7.

Pauk, F. R. (1953), Poznámky ke geologii Orlických hor a Králického Snì̌niku, Vestn. Ustred. Ustavu Geol., 28, 193-212.

Plesch, A., and O. Oncken (1999), Orogenic wedge growth during collision - Constraints on mechanics of a fossil wedge from its kinematic record (Rhenohercynian FTB, Central Europe), Tectonophysics, 309(1-4), 117-139, doi:10.1016/S0040-1951(99)00135-3.

Pouba, Z., K. Padira, and J. Fiala (1985), Omphacite granulite from the NE margin of the Bohemian Massif (Rychleby Mts), Neues Jahrb. Mineral Abh., 151, 29-52.

Pressler, R. E., D. A. Schneider, M. S. Petronis, D. K. Holm, and J. W. Geissman (2007), Pervasive horizontal fabric and rapid vertical extrusion: Lateral overturning and margin sub-parallel flow of deep crustal migmatites, northeastern Bohemian Massif, Tectonophysics, 443(1-2), 19-36, doi:10.1016/j.tecto.2007.07.003.

Přikryl, R., K. Schulmann, and R. Melka (1996), Perpendicular fabrics in the Orlické hory orthogneisses (western part of the Orlice-Sněžník Dome, Bohemian Massif) due to high temperature E-W deformational event and late lower temperature N-S overprint, J. Czech Geol. Soc., 41(3-4), $156-166$.

Rey, P. F., C. Teyssier, and D. L. Whitney (2009), The role of partial melting and extensional strain rates in the development of metamorphic core complexes, Tectonophysics, 477(3-4), 135-144, doi:10.1016/j. tecto.2009.03.010.

Ring, U., and M. T. Brandon (1999), Ductile deformation and mass loss in the Franciscan Subduction Complex: Implications for exhumation processes in accretionary wedges, in Exhumation Processes: Normal Faulting, Ductile Flow and Erosion, edited by U. Ring et al., Geol. Soc. Spec. Publ., 154, 55-86, doi:10.1144/GSL.SP.1999.154.01.03.

Rychtár, J., and V. Rybák (1987), Gravimetrical mapping of the Jesenik Mts. Region Ostružná-Mikulovice, report, Geophys. Inst., Brno, Czech Republic.
Schmidt, S., and H.-J. Götze (1998), Interactive visualization and modification of 3D models using GIS functions, Phys. Chem. Earth, 23, 289-295, doi:10.1016/S0079-1946(98)00027-5

Schmidt, S., and H.-J. Götze (1999), Integration of data constraints and potential field modeling-An example from southern lower Saxony, Germany, Phys. Chem. Earth Part A, 24, 191-196, doi:10.1016/S14641895(99)00017-4.

Schneider, D. A., S. J. Zahniser, J. M. Glascock, S. M. Gordon, and M. Manecki (2006), Thermochronology of the West Sudetes (Bohemian Massif): Rapid and repeated eduction in the Eastern Variscides, Poland and Czech Republic, Am. J. Sci., 306(10), 846-873, doi:10.2475/ 10.2006.03

Schulmann, K., and R. Gayer (2000), A model for a continental accretionary wedge developed by oblique collision: The NE Bohemian Massif, J. Geol. Soc., 157, 401-416, doi:10.1144/jgs.157.2.401.

Schulmann, K., A. Kröner, E. Hegner, I. Wendt, J. Konopásek, O. Lexa and P. Stípská (2005), Chronological constraints on the pre-orogenic history, burial and exhumation of deep-seated rocks along the eastern margin of the Variscan orogen, Bohemian Massif, Czech Republic, Am. J. Sci., 305, 407-448, doi:10.2475/ajs.305.5.407.

Schulmann, K., O. Lexa, P. Štípská, M. Racek, L. Tajčmanová, J. Konopásek, J. B. Edel, A. Peschler, and J. Lehmann (2008), Vertical extrusion and horizontal channel flow of orogenic lower crust: Key exhumation mechanisms in large hot orogens?, J. Metamorph. Geol., 26, 273-297, doi:10.1111/ j.1525-1314.2007.00755.x.

Schulmann, K., J. Konopásek, V. Janoušek, O. Lexa, J. M. Lardeaux, J. B. Edel, P. Stípská, and S. Ulrich (2009), An Andean type Palaeozoic convergence in the Bohemian Massif, C. R. Geosci., 341(2-3), 266-286, doi:10.1016/j.crte.2008.12.006.

Seyferth, M., and A. Henk (2004), Syn-convergent exhumation and lateral extrusion in continental collision zones-Insights from three-dimensional numerical models, Tectonophysics, 382(1-2), 1-29, doi:10.1016/j. tecto.2003.12.004.

Skrzypek, E., P. Štípská, O. Lexa, K. Schulmann, and M. Lexová (2011a), Prograde and retrograde metamorphic fabrics - A key for understanding burial and exhumation in orogens (Bohemian Massif), J. Metamorph. Geol., 29, 451-472, doi:10.1111/j.1525-1314.2010.00924.x.

Skrzypek, E., K. Schulmann, P. Štípská, F. Chopin, J. Lehmann, O. Lexa, and J. Haloda (2011b), Tectono-metamorphic history recorded in garnet porphyroblasts: Insights from thermodynamic modelling and electron backscatter diffraction analysis of inclusion trails, J. Metamorph. Geol., 29, 473-496, doi:10.1111/j.1525-1314.2010.00925.x

Smulikowski, K. (1967), Eklogity Gór Śnieznickich w Sudetach (Eclogites of the Śnieżnik Mts in the Sudetes), Geol. Sudetica, 3, 157-174.

Smulikowski, K., and W. Smulikowski (1985), On the porphyroblastic eclogites of the Śnieżnik Mountains in the Polish Sudetes, Chem. Geol., 50(1-3), 201-222, doi:10.1016/0009-2541(85)90121-4.

Steltenpohl, M. G., Z. Cymerman, E. J. Krogh, and M. J. Kunk (1993), Exhumation of eclogitized continental basement during Variscan lithospheric delamination and gravitational collapse, Sudety Mountains, Poland, Geology, 21, 1111-1114, doi:10.1130/0091-7613(1993)021< 1111:EOECBD>2.3.CO;2.

Štípská, P., K. Schulmann, A. B. Thompson, J. Ježek, and A. Kröner (2001), Thermo-mechanical role of a Cambro-Ordovician paleorift during the Variscan collision: The NE margin of the Bohemian Massif, Tectonophysics, 332(1-2), 239-253, doi:10.1016/S0040-1951(00)00259-6.

Štípská, P., K. Schulmann, and A. Kröner (2004), Vertical extrusion and middle crustal spreading of omphacite granulite: A model of syn-convergent exhumation (Bohemian Massif, Czech Republic), J. Metamorph. Geol., 22(3), 179-198, doi:10.1111/j.1525-1314.2004.00508.x.

Štípská, P., F. Chopin, E. Skrzypek, K. Schulmann, O. Lexa, P. Pitra, J. E. Martelat, C. Bolinger, and E. Źáčková (2012), The juxtaposition of eclogite and mid-crustal rocks in the Orlica-Śnieżnik Dome, Bohemian Massif, J. Metamorph. Geol., doi:10.1111/j.1525-1314.2011.00964.x, in press.

Švancara, J., and M. Chlupáčová (1994), Hustotní model geologické stavby podél geotraverzu 9HR a nadstavbové zpracování tíhového pole západní části Českého masívu. Zpráva za státní úkol: Geologický model západni části Ceského masívu ve vazbě na ultrahluboký vrt KTB v SRN, report, 38 pp., Cesk. Geol. Ustav, Prague.

Svoboda, J. (1966), Regional Geology of Czechoslovakia: Part I, Bohemian Massif, 668 pp., Geol. Surv. Czech., Prague.

Teisseyre, A. K. (1968), The Lower Carboniferous of the Intra-Sudetic Basin; Sedimentary petrology and basin analysis, Geol. Sudetica, 4, 221-298.

Teisseyre, A. K. (1975), Sedimentology and paleogeography of the Culm alluvial fans in the western Intrasudetic Basin (central Sudetes, SW Poland), Geol. Sudetica, 9(2), 5-135. 
Teyssier, C., and D. L. Whitney (2002), Gneiss domes and orogeny, Geology, 30(12), 1139-1142, doi:10.1130/0091-7613(2002)030<1139: $\mathrm{GDAO}>2.0 . \mathrm{CO} ; 2$.

Turniak, K., S. Mazur, and R. Wysoczański (2000), SHRIMP zircon geochronology and geochemistry of the Orlica-Śnieżnik gneisses (Variscan belt of Central Europe) and their tectonic implications, Geodin. Acta, 13, 293-312, doi:10.1016/S0985-3111(00)01045-7.

Vangerow, E. F. (1943), Das Normalprofil des Algonkium und Kambriums in den mittleren Sudeten, Geol. Rundsch., 34, 10-12, doi:10.1007/ BF01805371.

Verner, K., D. Buriánek, S. Vrána, L. Vondrovic, J. Pertoldová, P. Hanžl, and R. Nahodilová (2009), Tectonometamorphic features of geological units along the northern periphery of the Moldanubian Zone (Bohemian Massif), J. Geosci., 54(2), 87-100, doi:10.3190/jgeosci.046.

Warren, R. G., and D. J. Ellis (1996), Mantle underplating, granite tectonics, and metamorphic P-T-t paths, Geology, 24(7), 663-666, doi:10.1130/ 0091-7613(1996)024<0663:MUGTAM>2.3.CO;2.

Whitney, D. L., C. Teyssier, and O. Vanderhaeghe (2004), Gneiss domes and crustal flow, in Gneiss Domes in Orogeny, edited by D. L. Whitney, C. Teyssier, and C. S. Siddoway, Spec. Pap. Geol. Soc. Am., 380, 15-33.

Žáčková, E. J Konopásek, P. Jeřábek, F. Finger, and J. Košler (2010), Early Carboniferous blueschist facies metamorphism in metapelites of the West Sudetes (Northern Saxothuringian Domain, Bohemian Massif), J. Metamorph. Geol., 28(4), 361-379, doi:10.1111/j.1525-1314.2010.00869.x.
Żelaźniewicz, A., S. Mazur, and J. Szczepański (2002), The LadekŚnieżnik Metamorphic Unit-Recent State of Knowledge, Geolines, 14, $115-125$.

Żelaźniewicz, A., I. Nowak, A. Larionov, and S. Presnyakov (2006), Syntectonic Lower Ordovician migmatite and post-tectonic Upper Viséan syenite in the western limb of the Orlica-Śnieżnik Dome, West Sudetes: U-Pb SHRIMP data from zircons, Geol. Sudetica, 38, 63-80.

F. Chopin, J. R. Dujardin, J. B. Edel, K. Schulmann, E. Skrzypek, and P. Štípská, École et Observatoire des Sciences de la Terre, Institut de Physique du Globe, CNRS UMR 7516, Université de Strasbourg, 1 rue Blessig, F-67084 Strasbourg, CEDEX, France. (fchopin@unistra.fr)

M. Corsini, Géoazur, CNRS UMR 6526, Université de Nice, Sophia Antipolis, 28 av. Valrose, F-06108 Nice, France.

J. Lehmann, Czech Geological Survey, Klárov 3, CZ-11000 Prague, Czech Republic.

O. Lexa, Institute of Petrology and Structural Geology, Charles University, Albertov 6, CZ-12843 Prague, Czech Republic.

J. E. Martelat, Laboratoire de Géologie de Lyon, CNRS UMR 5276, Université Claude Bernard, F-69622 Villeurbanne, France.

P. Pitra, Géosciences Rennes, CNRS UMR 6118, Université Rennes 1, Campus de Beaulieu, F-35042 Rennes, CEDEX, France. 